\title{
Para uma crítica do constitucionalismo social: fragmentos weimarianos
}

\author{
For a critique of social constitutionalism: \\ weimarian fragments
}

Thiago Lemos Possas ${ }^{1}$

Enfrentamos o terceiro milênio como o irlandês anônimo que, perguntando sobre o caminho para Ballynahinch, refletiu e disse: "Se eu fosse você, não começaria por aqui".

Mas é por aqui que temos que começar.

Eric Hobsbawm (2007)

\begin{abstract}
Resumo: O presente artigo tem como objetivo a problematização dos limites e das possibilidades ínsitos ao constitucionalismo social resgatando, para tanto, algumas discussões travadas por juristas da República Weimar. Algumas concepções apontavam a possibilidade de se chegar ao socialismo através do Direito e do Estado Social, outras viam no "Capitalismo de Estado" o horizonte definitivo de conformação social com o controle das temíveis crises do capitalismo,
\end{abstract}

1 Possui graduação em Direito pela Universidade Federal de Minas Gerais (2008). Mestre em Direito Público pela UNESP. Doutor em Direito Econômico pela USP. Professor da Faculdade São Luís (Cursos: Direito e Filosofia). E-mail: thiagolp84@yahoo.com.br 
enquanto outras teorias visavam, ao contrário, ressaltar justamente o conflito ínsito ao Estado Social e sua racionalização, ou mesmo a impossibilidade de se transformar radicalmente a realidade fazendo uso dos instrumentos jurídicos de então. Esse mosaico de ricas teorias do Estado, da política e da Constituição servirá à crítica ao constitucionalismo social e ao apontamento das possibilidades nele inscritas e dos limites situados nas mesmas.

Palavras-chave: República de Weimar. Estado de Direito. Constitucionalismo Social. Capitalismo de Estado. Império do Direito.

Abstract: The present article has as objective the problem of the limits and the possibilities of participation in the social system, for this reason, some discussions waged by jurists of the Weimar Republic. Some conceptions pointed to a possibility of reaching socialism through Social Law and State, other ways of doing capitalism, while other theories aimed, on the contrary, to emphasize precisely the impossibility of radically moving reality by making use of the legal instruments of the time. This mosaic of rich theories of the state, of politics and of the constitution will serve to criticize social constitutionalism and to point out the possibilities in subscribers and the conditions situated in them.

Keywords: Republic of Weimar. Rule of Law. Social Constitutionalism. State Capitalism. Law's Empire.

\section{Introdução}

A experiência socialdemocrata de Weimar é pródiga em elementos para discussão sobre o alcance, as possibilidades e 
limitações do Estado Social e de seus Direitos Sociais. Vários autores trouxeram, à época, reflexões que até hoje servem de parâmetro para as discussões que orbitam em torno da questão do Estado Social.

O presente artigo não tem a menor pretensão de resumir o extensíssimo cabedal de ideias que figuraram nas discussões públicas acerca do Direito e do Estado sob a República de Weimar, mesmo porque tal esforço acadêmico foi realizado de maneira erudita por autores que se debruçaram especificamente sob o legado de Weimar (vide, por exemplo: BERCOVICI, 2004; HERRERA, 2012; HERRERA, 2002).

A ideia é, aqui, compor um brevíssimo mosaico com alguns posicionamentos de autores do contexto histórico indicado, não necessariamente obedecendo a uma cronologia, mas ressaltando questões como a da transição para o socialismo e o papel do Estado e do Direito neste processo, ou mesmo a impossibilidade da passagem de um modelo socioeconômico a outro por meios jurídicos.

Um dos elementos que figurou nesta discussão, como lembra Herrera, a título de exemplo, foi justamente a relevância política do sufrágio universal na Alemanha, que explicaria a evolução da socialdemocracia que considerou, à época, que uma mudança no sistema eleitoral seria suficiente para permitir aos trabalhadores a conquista do poder de forma pacífica. Mas, o que se viu ao final foi um indiscutível fracasso do projeto constitucional, pois uma "democracia dialética" que, segundo Fraenkel, possibilitaria o progresso pacífico articulado legislativamente pelo proletariado por meio do princípio majoritário, não resistiu ao capitalismo monopolista, e o direito privado acabou por absorver e preponderar sobre a estrutura constitucional (HERRERA, 2002, pp. 29, 45). 


\section{A mudança no (e pelo) Direito: elementos da experiência de Weimar}

Na periodização estabelecida por Carlos Miguel Herrera, pode-se apontar, num período "pré-weimariano", que a socialdemocracia enxergava a socialização como produto da própria evolução da economia planificada juridicamente. Essencial a tal evolução seria o enquadramento proporcionado pelo Direito do Trabalho, pelos contratos coletivos de trabalho, com o reconhecimento dos sindicatos e do papel por eles desempenhado no processo econômico (HERRERA, 2002, p. 32).

Segundo Herrera, neste período, defendia a socialdemocracia a manutenção da ordem estatal, sendo considerada, majoritariamente, como "o partido do Estado" numa república democrática, desde que o Estado fosse democrático. Tal posicionamento indicava o abandono de uma revolução social imediata, o que não entrava em choque com o programa do partido, já que, segundo Kautsky, a socialdemocracia era um partido revolucionário, "não um partido que fazia revoluções". A estabilidade trazida pela ordem burguesa favoreceria a força de integração da socialdemocracia, e a estabilidade jurídica não estaria em contradição com a mudança social. Herrera destaca que a adesão da socialdemocracia à Constituição de Weimar pode ser ilustrada claramente pelo programa do partido adotado no ano de 1921, que declarava, entre outras coisas, que "nous lutons pour la domination de la volonté organisée du peuple sur l'économie dans l'Etat populaire libre, pour le renouvellement de la société dans um sprit socialista general" (HERRERA, 2002, p. 32-33, 35).

A socialdemocracia demonstrava, segundo Herrera (apoiando-se em G. Könke), otimismo com relação ao crescimento e estabilidade em seu pensamento econômico, ao 
qual correspondia uma postura igualmente otimista diante do direito e da "estatalidade" no domínio da política. A despeito da crise econômica no contexto dos anos 1929-1930 e das tentativas de mudanças no regime, vislumbrava-se a viabilidade do projeto de integração social, figurando a Constituição como o instrumento necessário para levá-la adiante. Inicialmente foram adotadas, segundo o autor, leis que supostamente concretizariam a constituição econômica, como a lei atinente aos conselhos de empresas, que regulamentou o artigo 165 da Constituição, as convenções coletivas de trabalho se generalizaram nas empresas, restando construir, destarte, uma teoria jurídica socialista, ou categorias jurídicas, ao menos, para se pensar a nova ordem jurídica, sendo que os próprios programas partidários da socialdemocracia representaram reflexo dessa necessidade, ao conferirem um considerável espaço para a temática do direito. Esse otimismo pode ser exemplificado pelas conceptualizações empreendidas por H. Sinzheimer, "o jurista de confiança dos sindicatos", e também por suas tomadas de posições políticas, compreendendo o contexto como uma fase transicional em que não se está completamente imerso em um capitalismo privado, ao mesmo tempo em que ainda não se chegou ao socialismo (HERRERA, 2002, p. 36).

A reflexão sobre a nova ordem constitucional seria balizada, ainda na análise de Herrera, pelo Direito Social, categoria que já tinha uma longa história no pensamento jurídico alemão. Sinzheimer concebia o novo direito como um direito social, que seria expressão, em virtude de seu caráter dinâmico, da sociedade como um processo. Não seria simplesmente um novo conteúdo do direito, mas também um novo tipo de pensamento jurídico, que apontaria para a tarefa da autodeterminação social. O fim do Estado autoritário implicaria, na análise do advogado alemão, não apenas 
em uma nova política, mas também em um novo direito social, ancorado em duas demandas essenciais: a socialização da economia e um novo direito trabalhista. Herrera aponta que, do ponto de vista constitucional, o direito social dotaria o compromisso de Weimar de sentido jurídico-político socialista, direito social que parecia representar um estado intermediário entre o direito burguês e o socialista ou, mais precisamente, o elemento condutor da transformação do direito (HERRERA, 2002, p. 37).

Ocorre que o planejamento institucional, que deveria levar à mudança social, assim como a supremacia da soberania do povo, começa a mostrar suas limitações, em contradição com o texto constitucional de Weimar. O controle de constitucionalidade de leis exercido pelos juízes de então foi percebido como uma vitória momentânea da burguesia no terreno constitucional, a fim de impedir que o poder legislativo transformasse o Estado de Direito através do princípio da igualdade material (HERRERA, 2002, p. 39).

$\mathrm{O}$ que ocorreu, de maneira mais geral, na experiência weimariana, de acordo com Bercovici, foi a perda da legitimidade e da capacidade de ação do sistema político quando se deparou com crises agudas de modernização econômica, social e cultural, o que inviabilizou o cumprimento dos compromissos do constitucionalismo social alemão. A crise econômica se agrava profundamente em 1929, o que faz recrudescer a reação conservadora contra a socialdemocracia e os direitos sociais previstos constitucionalmente. Neste contexto, ganha vulto a opção autoritária defendida por Carl Schmitt, propugnando a convivência de um Estado forte (autoritário) com uma economia de mercado livre, em contraste com Estado Social desenhado pela Constituição de 1919 (BERCOVICI, 2004, pp. 21-23). 
Sobre o conturbado período e a opção pela ditadura com solução para a crise, assevera Bercovici que,

em 1932, Estado Autoritário era, segundo Hermann Heller, a palavra de ordem na Alemanha. Os defensores desta saída autoritária da crise eram os mesmos círculos políticos, econômicos e militares que, desde 1918, atribuíam todos os males à democracia e à Constituição de Weimar, com uma fé miraculosa na ditadura. Fé que só veio a aumentar com as dificuldades de formação de uma maioria política estável no Parlamento, a exigência de uma democracia social pelos trabalhadores e a crise econômica mundial, iniciada em 1929 (BERCOVICI, 2004, p. 109).

\subsection{Teoria do Estado e Realidade}

O contraponto mais evidente à posição autoritária schimittiana é a teoria de Hermann Heller e sua defesa enfática da Constituição e da República de Weimar, assegurando haver um caminho dentro das institucionalidades vigentes, com o aprofundamento de seu conteúdo, o que levaria a um Estado Social de Direito cuja inclusividade abrangeria a população integralmente em um sistema de democracia política, social e econômica (BERCOVICI, 2004, p. 23):

Boa parte do trabalho de Heller durante a República de Weimar consiste, justamente, em contestar as visões schmittianas de exceção permanente, ditadura e Estado Total, entendendo a superação do Estado de Direito liberal pelo Estado Social de Direito como única maneira de integrar os trabalhadores no Estado e, ao mesmo tempo, salvar a democracia e a Constituição (BERCOVICI, 2004, p. 110).

A Teoria do Estado helleriana é uma "ciência engajada", e o "conhecimento sobre o Estado tem que partir do pressuposto que a vida estatal sempre inclui aquele que a investiga, havendo uma identidade dialética entre sujeito 
e objeto de estudo". É engajada a visão do jurista alemão, também, pois se vincula "às concepções políticas socialistas", objetivando, justamente, a realização de um Estado Socialista. Bercovici ressalta que para Heller a "Teoria do Estado é, portanto, uma ciência da realidade, que estuda o Estado enquanto realidade, ou seja, enquanto formação real e histórica" (BERCOVICI, 2004, pp. 110-111). Heller defende que a "Teoria do Estado propõe-se investigar a específica realidade da vida estatal que nos rodeia. Aspira a compreender o Estado na sua estrutura e função atuais, o seu devir histórico e as tendências de sua evolução" (HELLER, 1968, p. 21).

$\mathrm{Na}$ tentativa de conciliar democracia e socialismo, Heller, segundo Bercovici, apresentaria como "problema central de sua concepção de Estado" as "relações entre pluralidade e unidade, visando a construção de uma unidade política com homogeneidade social em uma sociedade pluralista", ou como ele mesmo afirmou, "toute politique consiste das l'organisation et dans le maintien de cette unité", figurando justamente neste "equilíbrio dialético entre a unidade e a diversidade infinita dos atos sociais para a obtenção de uma unidade política ordenadora e ordenada" a essência do político para o jurista alemão (BERCOVICI, 2004, pp. 112, 114; HELLER, 2001, p. 201).

O político não é estático, mas deve se moldar constantemente de acordo com a realidade social. A política, para Heller, é um processo dinâmico pelo qual o Estado chega a ser e se impõe como unidade na pluralidade. Assim, a política é, também, a ordem da cooperação entre as relações humanas, sendo a finalidade da política estatal a busca pela ordem da cooperação das relações sociais em determinado âmbito (BERCOVICI, 2004, pp. 114-115).

Heller vê a democracia como o poder (ou a "dominação") do povo. E se o povo deve governar, cabe a ele produzir a "unidade de decisão e ação" mencionada, num 
sistema de unificação das vontades. O jurista aponta que a especificidade do poder democrático reside na designação dos representantes pela coletividade, e que os mesmos não serão os detentores da soberania, mas apenas "magistrados" escolhidos pelo povo, devendo ser nomeados e referendados de forma direta ou indireta pelo próprio povo, havendo uma ligação jurídica dos representantes aos representados. A democracia, desta maneira, deve ser a formação consciente desta unidade política ascendente, em que a representação resta dependente juridicamente da vontade popular. E assim, "le peuple comme multiplicité doit s'autoconstituer consciemment lui-même comme peuple em tant qu'unité". Esta homogeneidade social, no entanto, adverte o autor, não poderá vir a significar a abolição da estrutura antagonista da sociedade, engendrando uma comunidade pacífica sem oposições. Mas, lado outro, sua existência depende da existência da integração social (HELLER, 2001, pp. 203, 204, 205).

Ocorre que a consciência da liberdade, por parte do proletariado, significa tanto a consciência da desigualdade social quanto a consciência de poder político que ele possui. Caso o proletariado entenda que a igualdade dos direitos democráticos é um forte adversário que condenará a luta de classes nas formas democráticas ao insucesso, ele apelará à ditadura. Além disso, a disparidade social pode desacreditar completamente a democracia e o seu princípio da igualdade: "l'égalité formelle la plus radicale se transforme em inégalité la plus radicale em l'absence d'homogénéité sociale, et la démocratie formelle se transforme en dictadure de la classe dominante" (HELLER, 2001, pp. 206, 207).

Para Heller, a partir da aquisição da consciência da desigualdade social, restará ao proletariado o desejo de tomar o Estado. Só haverá respeito à forma que a democracia estabelece para a luta de classes se o regime propiciar 
expectativas de sucesso à luta dos trabalhadores. Caso isso não ocorra, o proletariado enxergará a instituição estatal como aparato classista opressor que deve ser enfrentado, estabelecendo-se, em seu lugar, a ditadura do proletariado. A democracia estava seriamente ameaçada em virtude da falta de homogeneidade social e de um poder econômico suficiente para fazer frente às divisões sociais (BERCOVICI, 2004, p. 127).

Fica claro, a partir desta discussão, que Heller não era um revolucionário, propriamente, mas um reformista, na linha de Lassale, que buscou conjugar a teoria do Estado hegeliana com a leitura econômica marxista, propugnando um autêntico Estado operário com elevado grau de socialização entre as pessoas. O marxismo "possuía o mérito de ter uma visão de totalidade, reagindo às tentativas liberais de isolar o Estado da realidade social. No entanto, o marxismo subordinou a atividade estatal à atividade social, entendendo esta última como exclusivamente econômica". Crítico do "determinismo econômico do marxismo", Heller também divergia da visão marxista acerca do Estado e da ditadura do proletariado, com seu direcionamento ao fenecimento da instituição estatal. Para o autor, o Estado não poderia ser concebido em função da economia, embora fosse essencial a relação entre as estruturas econômica e social para sua compreensão. O Estado deveria, destarte, ser compreendido a partir da realidade social enquanto totalidade, da qual a economia desponta como um momento apenas (embora decisivo) do sistema capitalista. Em suma, Heller não consegue pensar a partir da extinção do Estado, sendo este apenas transformado pelo socialismo (BERCOVICI, 2004, pp. 116-117).

Heller vê o socialismo como o ponto de chegada do desenvolvimento democrático, o momento culminante da libertação dos trabalhadores: 
Hermann Heller entende o liberalismo e o socialismo como momentos na evolução da democracia. O liberalismo e a democracia burguesa aspiravam alcançar uma harmonia pré-estabelecida da ordem natural espontânea pelo livre jogo dos egoísmos individuais. Já o socialismo quer estabelecer uma sociedade solidária, colocando no lugar do governo sobre os homens, o governo sobre os bens. Em suma, a democracia liberal consolidou a emancipação da burguesia. A democracia social pretende a emancipação do proletariado. Neste sentido, o socialismo, para Heller, significa democracia social, reconhecendo apenas o povo, em sua totalidade socialmente solidária, como fundamento para justificar o governo. Como o terreno econômico e o mais opressor, por não ter sido fixado juridicamente pelo liberalismo, o socialismo aspira não apenas a igualdade entre as classes, mas a socialização econômica, dando importância fundamental a organização equitativa das relações socioeconômicas (BERCOVICI, 2013, pp. 131-132).

A burguesia identificou uma séria ameaça advinda da intensificação da participação dos proletários no Parlamento, sob a égide da igualdade formal, que poderia levar à limitação do poder econômico por meio do Direito, com a submissão de tal poder ao Estado de Direito, a exigência das prestações sociais e mesmo a relativização do direito de propriedade, contido, inclusive, na Constituição de Weimar. A convivência entre democracia e capitalismo acaba gerando, para Heller, uma situação ameaçadora para a própria classe burguesa. A solução lógica para que a burguesia fizesse frente ao poder dos trabalhadores foi o vilipêndio ao império da lei, buscando soluções autoritárias que assegurassem a preponderância de seu poder político e social. Ao rechaçar o Estado de Direito e a democracia, fruto de suas lutas revolucionárias, a burguesia renega sua própria história. Heller identifica o dilema alemão no começo da década de 1930 como sendo a opção entre o Estado de Direito e o fascismo (BERCOVICI, 2004, pp. 128-129).

Para Heller, a calculabilidade das relações sociais (econômicas, em especial) só se pode obter a partir da submissão 
a uma ordem unitária. Assim, o processo de racionalização social tem como resultado a edificação de um Estado de Direito. Este Estado de direito é essencialmente marcado pelo império da lei, lei que deveria pautar toda ação judicial e administrativa, diferentemente do que ocorria no Absolutismo, sendo que a intromissão na propriedade privada e na liberdade dos cidadãos ficava vedada, salvo se fundadas nas normas jurídicas. Para que houvesse a aludida calculabilidade, mister a configuração da separação de poderes, já que o poder não submetido a controle poderia se degenerar em poder arbitrário não calculável (HELLER, 1985, pp. 284-286).

Segundo Heller, o ideal de justiça perdeu sua validade para o legislador e se degradou em mera máxima de administração formal, que impunha sua aplicação calculada aos casos concretos. Mais uma vez coloca-se numa posição de centralidade a questão atinente à calculabilidade e segurança burguesas. A regulação legal da existência, estabelecida para garantia da segurança econômica, corresponderia à mera tecnificação em prol de uma mecanização despersonalizada, mais uma vez a servir à reprodutibilidade da sociedade capitalista (HELLER, 1985, pp. 287-289).

A situação à época, como anteriormente mencionado, leva a burguesia a uma interpretação pessimista do processo de normatização. O princípio democrático ameaça a supremacia burguesa que começa a renegar seu próprio universo cultural com a ameaça representada pelo próprio ideal do Estado de Direito. Mesmo porque, a reivindicação por uma democracia social, advinda do proletariado, significa a extensão da ideia de um Estado material de Direito ao mundo do trabalho e das trocas mercantis, o que é totalmente rechaçado pela classe burguesa que não quer perder sua hegemonia. A opção pela Ditadura passa a figurar como redentora no horizonte burguês (HELLER, 1985, p. 290). 
A proposta helleriana é o avesso da proposta burguesa autoritária, com a defesa da intensificação do Estado de Direito no sentido do Estado Social de Direito. Se no fim do Medievo, segundo o autor, o poder político se enredou numa luta que mirava a autonomia diante do poder religioso, no princípio do século $\mathrm{XX}$ a luta a ser travada era contra o poder econômico (BERCOVICI, 2004, pp. 129-130). Heller, portanto, seguiu na defesa do Estado Social que era, a bem da verdade, um Estado socialista:

A opção de Heller pelo Estado Social não se destinava a aperfeiçoar ou a legitimar o capitalismo, como fizeram os chamados Estados Sociais do pós-Segunda Guerra Mundial. Heller é anticapitalista e o seu Estado social de direito é um Estado socialista e democrático. Este é o principal aspecto emancipatório da proposta do Estado Social de Hermann Heller, que não pode ser, de maneira alguma, menosprezado ou relativizado (BERCOVICI, 2004, p. 133).

Por fim, cabe reforçar que Heller via na Constituição de Weimar uma abertura às forças sociais das "válvulas jurídicas" por meio das quais seria possível acabar com as contradições na sociedade. Esta abertura constitucional permitiria, inclusive, a passagem ao socialismo, figurando o texto constitucional como uma plataforma para o futuro, viabilizadora da realização das transformações sociais necessárias de maneira pacífica. O jurista alemão não identificava o obstáculo da transição ao socialismo na forma jurídica, mas na ausência de poder dos socialistas. Seria justamente a integração dos trabalhadores junto ao Estado que finalizaria a revolução burguesa e daria início ao socialismo (BERCOVICI, 2004, pp. 136, 137, 138). 


\subsection{O capitalismo de Estado}

Vários outros autores conviveram com Heller e prestaram também relevantes contribuições para discussão sobre a variada temática weimariana. Na seara marxista, por exemplo, houve, segundo Rugitsky, um importante debate travado na passagem do século XIX para o XX (até a Primeira Guerra) que tinha como questão central a hipótese de as crises econômicas redundarem no colapso do sistema capitalista ("controvérsia sobre o colapso"). A guerra provocou divisões no movimento socialista, com a contraposição entre a socialdemocracia alemã e os bolcheviques, o que levou ao enfraquecimento do referido debate. Bolcheviques entendiam que o capitalismo passava por uma crise que desembocaria em sua destruição, mesmo que não houvesse colapso econômico, enquanto a socialdemocracia alemã entendia que o capitalismo se fortalecia e tendia à estabilização. Esta "racionalização neutra" pela qual passava o capitalismo levaria à transformação do próprio sistema, em direção ao socialismo. Esse raciocínio não foi endossado pelos bolcheviques, que afirmavam que as transformações pelas quais passava o sistema econômico aprofundavam suas contradições, aproximando o momento de sua crise final (RUGITSKY, 2008, pp. 54-55, 58).

Dentre os autores da contenda anunciada, Friedrich Pollock não via, segundo Marramao, a crise de 1929 como o início do fim do capitalismo, mas como representação, tão somente, dos estertores do capitalismo concorrencial, ou seja, o capitalismo permaneceria, mas não mais em sua forma liberal, havendo uma reorganização do sistema econômico por meio da planificação da economia. Nesta nova configuração do capitalismo caberia ao economista esboçar modelos de planificação, contribuindo para a orientação da 
futura política econômica a ser desenvolvida pelo Estado. A este respeito, Pollock aponta dois modelos fundamentais de economia planificada: o capitalista, que seria caracterizado pela manutenção da propriedade privada dos meios de produção, e o socialista, marcado essencialmente pela propriedade coletiva dos meios de produção (MARRAMAO, 1990, pp. 217-218; Cf. RODRIGUEZ; RUGITSKY, p. 271, 2008).

Pollock afirmava que a crise pode ser superada por meios capitalistas, através da organização da economia pela sua planificação:

Pollock não nega o caráter "catastrófico" da crise; ao contrário, ataca, muito mais vivamente, as representações harmonizadoras do "capitalismo pré-bélico", que minimizam as enormes destruições produzidas pelo "automatismo" do mercado, definindo-as como "friç̧ões"; mas não a considera como o memento mori (como Grossmann) do sistema, e afirma que pode ser superada por meios capitalistas. O mecanismo do mercado já não é capaz de produzir a "adaptação ótima" das forças produtivas às exigências; daí, a necessidade do reordenamento planificado (MARRAMAO, 1990, p. 219).

A obra de Pollock se situaria numa posição peculiar em todo este debate, diferenciando-se de ambas as correntes principais para anunciar que "as transformações do capitalismo impediriam a ocorrência de futuras crises econômicas" (RUGITSKY, 2008, p. 55). No capitalismo de Estado o controle governamental evita sérias distorções do sistema econômico, assim como os problemas que antes atormentavam os economistas são convertidos em meros problemas administrativos:

Government control of production and distribution furnishes the means for eliminating the economic causes of depressions, cumulative destructive processes and unemployment of capital and labor. We way even say that under state capitalism economics as a social science has lost its object. Economic problems in the old sense no longer exist when the coordination of all economic activities is effected by conscious plan 
instead of by natural laws of the market. Where the economist formerly racket his brain to solve the puzzle of the exchange process, he meets, under state capitalism, with mere problems of administration (POLLOCK, 1941, p. 217).

Pollock, segundo Marramao, aponta a "tendência da direção capitalista para intervir ativamente na dinâmica do conflito entre as forças produtivas e as relações de produção". Haveria uma tendência, no longo prazo, de concentração em "grandes unidades" ou mesmo para o Estado do poder de disposição sobre o capital, em detrimento do poder do proprietário individual. As experiências históricas da época, desde o nazismo alemão até o New Deal norte-americano, representaram a racionalização dos processos econômicos advinda do acordo entre poderosos grupos monopolistas que decidiam os rumos da economia, começando a se esboçar a forma de organização capitalista na qual há a interferência direta do Estado (MARRAMAO, 1990, pp. 226-228; Cf. RODRIGUEZ; RUGITSKY, p. 274, 2008).

Em suma, Pollock afirma que o desenvolvimento social e econômico ocorrido na Europa pós-primeira guerra pode ser interpretado como um processo de transição do capitalismo privado para o capitalismo de Estado. Esta nova conformação do capitalismo é marcada pela assunção de importantes funções do capitalismo privado pela própria instituição estatal, o que não significa uma mudança para o regime socialista, e dá ensejo a dois tipos opostos de Estado: o democrático e o totalitário, ambos representando a nova configuração do capitalismo de Estado. O mercado é destituído da função de controle da coordenação da produção e distribuição, que foi assumida por um sistema de controle direto, estando a liberdade comercial, de empresa e o trabalho sujeitos à intervenção estatal (POLLOCK, 1941, pp. 200, 201). 
Um plano geral daria, segundo Pollock, direção para a produção, para o investimento, o consumo, poupança, significando a planificação do processo econômico a construção de um plano em escala nacional para a realização de determinados objetivos com todos os recursos disponíveis (POLLOCK, 1941, p. 204).

Pollock destaca as vantagens advindas das técnicas de distribuição do capitalismo de Estado:

Given a general plan and the political power to enforce it, state capitalism finds ample technical means for distributing everything that can be produced with the available resources. The main difficulty of private capitalism is eliminated by fact that under state capitalism the success of production does not necessarily depend upon finding buyers for the product at profitable prices in a unstable market, but is consciously directed towards satisfying public and private wants which are to a large extent defined in advance (POLLOCK, 1941, p. 211).

Não haveria uma relação necessária estabelecida por Pollock entre planificação da economia e socialismo:

Para ele [Pollock], a economia planificada consiste em um sistema econômico cuja produção e distribuição são reguladas de forma centralizada por um planejamento social. Se tal economia for baseada na propriedade privada dos meios de produção e em uma sociedade de classes, será uma economia planificada capitalista. Por outro lado, se for caracterizada pela propriedade pública dos meios de produção e por uma sociedade sem classes, será uma economia planificada socialista (RUGITSKY, 2008, p. 64).

Conceito de capitalismo de Estado elaborado por Pollock em 1941 pode ser considerado o ponto alto de sua produção intelectual, significando a "retirada do mercado da função de coordenador da produção e da distribuição, substituída por um sistema de controles diretos exercidos pelo Estado. Consequentemente, livre comércio, livre iniciativa e trabalho livre seriam praticamente abolidos". Este modelo se estruturaria em cinco elementos centrais, a 
saber: um plano geral de direção da produção, distribuição, poupança e investimento; os preços não flutuariam livremente, sendo também regulados pelo plano; subordinação do lucro ao plano, não podendo se contrapor aos objetivos nele estipulados; no lugar do improviso nas atividades do Estado, entra em cena uma grande racionalização e mesmo uma "administração científica"; e, por fim, há a substituição dos meios econômicos por meios políticos como garantia da reprodução da vida econômica, o que representa a transição da predominância econômica para a predominância política (RUGITSKY, 2008, pp. 60, 65).

O principal problema da sociedade planificada, segundo Pollock, não se encontra na esfera econômica, mas na esfera política, nos princípios a serem aplicados na decisão de quais necessidades devem ser priorizadas, quanto tempo deve ser gasto no trabalho, qual produto deverá ser consumido, entre outras coisas, decisões estas que não poderão ser completamente arbitrárias, mas dependem dos recursos disponíveis (POLLOCK, 1941, p. 204).

A planificação é imposta à sociedade pelo poder estatal para que nada essencial seja deixado ao funcionamento das leis do mercado, sendo totalmente repudiada a criação de uma esfera da economia em que não poderia a instituição estatal interferir, consoe era observado na época do capitalismo privado. A substituição do livre mercado pela planificação estatal não redunda na extinção da iniciativa privada, que poderá ser posta numa base mais ampla, mas será integrada dentro do enquadramento do plano geral (POLLOCK, 1941, pp. 206-207).

Rugitsky salienta que o capitalismo de Estado representou uma reorganização planificada da economia, na qual a instituição estatal figura como o principal capitalista. O autor destaca a afirmação de Pollock, em texto de 1932, de que 
seria concebível a existência de uma economia planificada socialista, na qual os meios de produção seriam estatais. Já no texto de 1941, Pollock apresenta uma dicotomia de capitalismos de Estado compreendendo os modelos democrático e totalitário, sendo o primeiro controlado pelo povo. Ou seja, “aquilo que era designado economia planificada socialista em 1932 passa a ser designado capitalismo de Estado democrático em 1941" (RUGITSKY, 2008, p. 66).

Rugitsky afirma não haver uma oposição completa entre a ideia de economia planificada socialista, tal como tratada no texto de 1932, e o "diagnóstico socialdemocrata da estabilização, relacionado à controvérsia sobre o colapso". Neste sentido, "a transição para o socialismo passava a depender unicamente da tomada do poder do Estado, que passaria a controlar a produção já socializada". Com o proletariado controlando a instituição estatal, haveria a conversão da economia planificada capitalista para a socialista, baseada numa sociedade sem classes e com os meios de produção sendo públicos. Pollock romperá com a temática da estabilização através da formulação do conceito de capitalismo de Estado. A própria experiência histórica da década de 1930 (nazismo, estalinismo) mostra a "ingenuidade da estratégia socialdemocrata", restando evidente que há "um processo burguês de reestruturação que afasta a perspectiva de superação do capitalismo", havendo mesmo a consolidação do sistema capitalista quando de sua regulação consciente. $\mathrm{O}$ capitalismo de Estado, portanto, leva à primazia da política, reorganizando a economia, mas sem dar ensejo à substituição do capitalismo pelo socialismo. A alternativa posta pelo autor era entre a democracia e o totalitarismo, não sendo posta a questão da alternativa ao capitalismo (RUGITSKY, 2008, pp. 66-67). 
Rugitsky destaca, interpretando Pollock², que não haveria qualquer limite, do ponto de vista econômico, ao funcionamento do capitalismo de Estado. A capacidade adaptativa do capitalismo deu ensejo a uma "mudança qualitativa do modo de produção", prejudicando as previsões de colapso. O conceito de capitalismo de Estado traria uma mudança ainda maior:

a própria dinâmica econômica foi bloqueada e não cabe sequer continuar discutindo as crises. Sintomático dessa conclusão é o fato de que Pollock, em uma nota de rodapé do artigo sobre capitalismo de Estado, questiona se ainda cabe a utilização da categoria valor quando já não há uma economia de mercado. Negar a teoria do valor é negar a lei de movimento do capital como determinação abstrata da dinâmica do modo de produção, formulada dessa maneira por Marx (RUGITSKY, 2008, p. 68).

\subsection{O “Império da Lei” e os conflitos sociais}

Outro jurista que prestou relevante contribuição teórica para a compreensão da República de Weimar foi Franz Neumann. Diferentemente do diagnóstico de Pollock que,

2 Gilberto Bercovici (2016, online) também sintetiza de forma lapidar a visão pollockiana: “Pollock, pesquisador do Instituto para Pesquisa Social (Institut für Sozialforschung), exilado nos Estados Unidos, no final da década de 1930. A crescente intervenção do Estado na economia inspirou Frederick Pollock a desenvolver, com base nos elementos da experiência posterior à Primeira Guerra Mundial na Europa e, de certo modo, nos Estados Unidos, o modelo do capitalismo de Estado. No capitalismo de Estado, o Estado assume importantes funções econômicas, mas não implanta o socialismo, pois não suprime o mercado. O mercado simplesmente deixa de ser responsável pela coordenação da produção e distribuição, assumidas como tarefas estatais. Com a subsidiariedade do mercado, as questões econômicas são analisadas sob o enfoque político. Embora não seja mais possível a existência de uma esfera econômica privada sem a presença estatal, isso não significa o fim da livre iniciativa, mas sua integração a um plano geral, comandado pelo Estado". 
como visto, concebe a economia capitalista com forte teor de estabilização, Neumann destaca a sua conflituosidade (RODRIGUEZ; RUGITSKY, pp. 273-274, 2008).

Ao abordar o Estado de Direito, bem como o próprio papel das normas jurídicas, Franz Neumman opera uma importante distinção entre os contextos históricos do Estado de Direito liberal-burguês e o Estado Social da Constituição de Weimar. A idealização do Estado Liberal como instituição abstencionista, omissa com relação à interferência no processo econômico, e que figuraria com neutralidade diante da sociedade não se sustentava, já que o Estado não tinha pudores em demonstrar força em consonância com os interesses da classe burguesa: "Ele travou guerras e reprimiu greves, protegeu seus investimentos com fortes frotas, defendeu e ampliou suas fronteiras com fortes exércitos, estabeleceu 'paz e ordem' com a polícia" (NEUMANN, 2014, pp. 15-16).

Nesta sociedade burguesa da livre concorrência, o contrato ganha centralidade como elemento constitutivo da mesma, segundo o autor, na medida em que viabiliza o exercício da liberdade econômica individual, e serve de elemento mediador entre os proprietários, o que o torna "tão importante quanto a própria propriedade". Outro elemento essencial a este tipo de conformação social é o "império da lei" que significava a necessidade de que as medidas impostas à sociedade obedecessem à forma legislativa, ao mesmo tempo em que significava (a aludida primazia da lei) que a burguesia poderia exercer a contento sua influência sobre o poder político que se deslocou, no Estado Liberal, para o Parlamento. Tendo-se em vista, destaca Neumann, que a intervenção via legislação se dá, muitas vezes, direcionada ao instituto da propriedade privada ou mesmo da liberdade, fundamental que o controle desta possibilidade de ingerência em setores centrais à sociedade burguesa fique 
nas mãos da classe proprietária. E se as transformações na realidade passam, inapelavelmente, pelo Parlamento, nesta nova conformação do poder político pós-revoluções burguesas, "o império da lei parlamentar se torna ao mesmo tempo um meio de bloquear ou ao menos de parar o avanço social", sendo escamoteado pela doutrina, neste processo, "a relutância das classes dominantes em relação à reforma social, na medida em que a lentidão da máquina parlamentar transforma o único meio de mudança do direito em um meio para a preservação de sua imutabilidade" (NEUMANN, 2014, pp. 30, 41-42).

Neumann argumenta que a mesma doutrina que fica silente com relação ao veto imposto pela classe burguesa à reforma social teria a função ideológica de encobrimento dos "verdadeiros detentores do poder", com a invocação da lei como único soberano, do "government of laws and not of men", o que traz a ocultação de quem controla efetivamente o processo de feitura destas mesmas leis. Para que este sistema funcione satisfatoriamente para os interesses das classes proprietárias, fundamental que a burguesia controle mesmo o Poder Legislativo. Caso esse controle diminua, "então surgem no mesmo instante novas doutrinas jusnaturalistas destinadas a reduzir a supremacia de um Parlamento em que representantes do operariado também exerçam influência". Os juristas servem para a chancela da ambígua posição burguesa que também pode ser ambivalente no seguinte sentido, segundo o autor: "a afirmação enfática da autonomia humana corresponde a uma declaração igualmente apaixonada em favor do império da lei" (NEUMANN, 2014, p. 42).

Neumann compendia sua perspectiva sobre o Estado Liberal de Direito, levando em consideração a ideologia que o atravessa e o justifica: 
1. A estrutura formal do sistema jurídico: Essas liberdades são garantidas por meio do direito formal e racional, ou seja, por leis universais e por sua rigorosa aplicação por parte de juízes independentes, pela negação do caráter de criação do direito na atividade do juiz e ao ignorar as cláusulas gerais.

2. A estrutura material do sistema jurídico: Esse sistema jurídico estava economicamente vinculado à livre concorrência. Ela encontrava sua expressão nas garantias conexas da propriedade e nas liberdades de contrato e de comércio.

3. A estrutura social do sistema jurídico: Ele era socialmente orientado a uma situação em que a classe trabalhadora não era gravemente perigosa.

4. A estrutura política do sistema jurídico: Ele era politicamente relacionado a um sistema de divisão e de distribuição de poderes. Na Alemanha, estava orientado a uma situação em que a burguesia não tinha um papel crucial; na Inglaterra, a um sistema em que a burguesia determinava o conteúdo das leis e em que o poder parlamentar era dividido entre a coroa, a aristocracia e a burguesia (NEUMANN, 2014, pp. 53-54).

A não-intervenção estatal na sociedade liberal-capitalista significava, "na verdade, a intervenção em favor da classe dominante, ela significa que o economicamente forte pode ditar as condições de existência do economicamente fraco". O Estado Liberal não possuía uma "constituição econômica" expressa em seu texto constitucional, bem como a doutrina jurídica não chegou a desenvolver, naquele contexto, um direito econômico, muito em virtude da determinação peremp- 
tória do § 903 do Código Civil alemão de que o proprietário poderia tratar sua propriedade de acordo com sua vontade, podendo igualmente excluir a influência de terceiros sobre a mesma. Assim, a doutrina jurídica alemã ignorava que a nova ordem jurídica (social) interferia de maneira não negligenciável no curso dos processos econômicos, bem como ignorava a segunda parte da Constituição de Weimar que trazia a estruturação da intervenção estatal na economia (NEUMANN, 2017, p. 151).

Neumann ${ }^{3}$ aponta, outrossim, que houve uma mudança substancial na prática e no pensamento jurídico no período do capitalismo monopolista que iniciou seu período na Alemanha com a democracia weimariana. Um novo ator

3 Interessante síntese da perspectiva neumanniana pode ser encontrada em importante texto de Giacomo Marramao (1989, p. 172): “Na abordagem interpretativa de Neumann, tal como é esboçada nesse fundamental ensaio e em outros trabalhos do mesmo período, encontram-se condensadas e articuladas três ordens de considerações: 1) uma consideração de ordem metodológica geral, que poderia ser esquematicamente sintetizada do seguinte modo: Weimar representa um caso clamoroso de mudança de forma de um sistema capitalista desenvolvido, capaz de pôr em discussão tanto o esquema liberal tradicional quanto o marxista clássico (com efeito, ele requer um esforço de determinação da especificidade da estrutura política e da sua evolução interna); 2) uma consideração histórico-comparativa, segundo a qual o tipo de "racionalidade" daquele sistema devia ser assumido não somente num sentido genericamente estrutural (ou seja, sob o mero ângulo da "previsibilidade"), mas também em sentido "estritamente social": ao contrário da Inglaterra, onde a existência de uma racionalidade em defesa do status quo era garantida por um "desenvolvimento inteiramente inadequado das leis de proteção aos pobres", na primeira república alemã "as vantagens da racionalidade da lei orientavam-se em benefício da classe trabalhadora"; 3) uma consideração em chave de teoria e de história constitucional, que aponta a peculiaridade do sistema weimariano na relação biunivoca entre compromisso político e forma-contrato: a incidência do "político" no "social" se explicita na relevância específica que assumem as relações contratuais enquanto fatores de remodelação da sociedade - da estratificação e do conflito social". 
emergiu, naquele momento histórico, de forma a não mais poder ser ignorado, como o era na visão liberal de sociedade. O movimento operário ganha novo significado, segundo o autor, e o conflito classista não pôde mais ser negligenciado, devendo, em vez disso, ser contemplado na conformação de uma constituição (NEUMANN, 2014, p. 54-55).

Forjou-se, destarte, uma "democracia coletiva" na Alemanha, composta por organizações sociais autônomas, abarcando o pluralismo político presente na sociedade de classes:

Esse sistema de Weimar foi chamado de "democracia coletiva" porque a integração da vontade do Estado supostamente não deveria mais resultar da soma das vontades de cidadãos eleitores, mas da intermediação de organizações sociais autônomas. O Estado deveria se limitar a um papel de terceiro neutro entre essas organizações livres. Nesse sentido, a democracia de Weimar cumpre uma parte considerável das demandas do pluralismo político. A soberania do Estado não deve mais ser exercida por meio de uma burocracia independente, da polícia e do exército, mas supostamente deveria estar nas mãos da própria sociedade, que deveria se organizar de forma cooperativa para seu exercício. Esse sistema pluralista não ignorava mais a oposição entre classes, ele procurava antes transformar a oposição em uma cooperação entre classes (NEUMANN, 2014, p. 56-57).

Neumann entende que, diferentemente do liberalismo que ignorava a existência dos conflitos sociais, e via a consagração formal da liberdade e da igualdade jurídica como algo em si satisfatório, a democracia coletiva fundada no pós-guerra reconheceu e acolheu em seu interior o conflito classista, almejando transformá-lo, conforme citação acima. Neste período, os trabalhadores tornaram-se autoconscientes em virtude de sua organização política autônoma e tentativa de mudar a sociedade em consonância com seus anseios. $\mathrm{O}$ autor indica a aceleração dessa tendência com a guerra e a 
transformação do Estado burguês liberal em uma democracia de massas (NEUMANN, 2013b, p. 439-440).

Para Neumann, a Constituição de Weimar foi o "contrato social" deste novo pacto entre as diferentes classes sociais:

A ideia de paridade entre vários estratos da sociedade é uma teoria visível na formação da Constituição de Weimar. A história da Constituição de Weimar mostra que a concepção de um contrato social não é um mero ideal ou um mero artifício para a justificação do Estado, mas às vezes chega mesmo a ser uma realidade histórica. É estranho que ninguém tenha observado que a Constituição de Weimar foi de fato o trabalho de vários contratos sociais firmados entre vários grupos da sociedade (NEUMANN, 2013b, p. 440).

Erigiu-se na Alemanha, à época, uma "democracia coletivista", um "sistema de paridade" entre as classes, um sistema constitucional conhecido como Estado Social de Direito, no qual a instituição estatal se vale das instituições privadas para a realização de suas tarefas e, ao mesmo tempo, descentraliza na direção das mesmas o poder político: "entre o partido que negocia e aquele que colabora, o Estado age como um terceiro partido neutro, que deveria interferir somente se os oponentes sociais não chegassem a um acordo" (NEUMANN, 2013b, p. 442).

Ocorreu, portanto, a democratização da sociedade como um todo, constituindo-se em democracia de massas, com a aquisição de direitos políticos por grande parte do povo, havendo a tentativa de se estabelecer certo equilíbrio entre as classes, condensado nas próprias instituições constitucionais. O sufrágio universal passa a ser um indicativo de que o tempo de dominação burguesa pode ter acabado, e que os parlamentos, doravante, serão locais da representação também das classes trabalhadoras e da pactuação dos compromissos entre "os vários parceiros na luta de classes" (NEUMANN, 2013b, p. 443). 
Era a segunda parte da Constituição de Weimar, intitulada "Direitos fundamentais e obrigações fundamentais dos alemães", que estabeleceu o equilíbrio entre as classes sociais em disputa, abarcando tanto os direitos fundamentais liberais, da primeira geração, quanto os novos direitos sociais, de modo a compor um texto constitucional que incorporava as diferentes dimensões de direitos fundamentais e não tomava uma decisão expressa em favor de um dos grupos, sendo fundamentalmente uma "constituição sem decisão" (NEUMANN, 2014, p. 58-59).

Neumann destaca o princípio da igualdade consagrado na Constituição de Weimar e seu conteúdo positivo, material, para além da igualdade negativa típica do Estado liberal burguês. Igualdade positiva essa que "pode conter a exigência de não apenas criar as possibilidades jurídicas para que cada um possa participar dos bens da sociedade, mas pode também conter a exigência da possibilidade de fato". O autor afirma que seria discutível, apenas, "se a proposição de igualdade também exige uma igualdade econômica e social positiva ou se ao menos demanda que se comece com a realização da igualdade econômica e social", e se posiciona favoravelmente a esta tese, como sendo este o conteúdo do mandamento (NEUMANN, 2017, p. 143-144).

Neumann diferencia a democracia liberal, "uma democracia cujo âmbito objetivo de operação está apenas na manutenção da segurança burguesa, na proteção da liberdade e da propriedade da burguesia proprietária", da democracia social, "cujo âmbito objetivo de operação esteja na promoção da ascensão do operariado e que proteja a liberdade e a propriedade apenas na medida em que elas não se contraponham à ascensão do operariado", associando, portanto, o conceito de igualdade formal à democracia liberal burguesa e ao Estado Liberal, em que "cada um tem chances iguais no 
comércio e na troca", sendo impensável a concepção positiva de igualdade no Estado burguês (NEUMANN, 2017, p. 144):

Se a igualdade perante a lei fosse materialmente determinada, então faria parte das tarefas do Estado democrático realizar positivamente outros objetivos para além da defesa contra perturbações da liberdade e da propriedade da burguesia proprietária. Assim, surgiria um conflito insolúvel com esses direitos liberais de liberdade, que são santificados como direitos pré-estatais. Isso porque então seria necessário, para que todos - também o quarto estamento - pudessem tomar parte dos bens vitais, intervir, sob certas circunstâncias, na liberdade, na propriedade e na segurança da burguesia.

Se a proposição da igualdade serve, em certas teorias do Estado alemãs e americanas, à proteção do Estado de Direito burguês, Neumann pretende desenvolver noutra direção sua análise sobre a Constituição de Weimar e seu constitucionalismo social. Destaca, para esta finalidade, o artigo 151 do texto constitucional que traz, no que tange à regulação da constituição econômica, a ideia de "justiça", que ganha materialidade com a determinação de que a ordem econômica deverá garantir a todos existência digna, sendo que apenas nestes termos há a garantia da proteção da propriedade e das liberdades contratual e negocial. Além disso, a Constituição possui um arcabouço normativo direcionado para a realização da liberdade social, para a autodeterminação dos trabalhadores (NEUMANN, 2017, pp. 147, 149):

Mas a Constituição não contém apenas a determinação programática geral de que a ordem da vida econômica deve ter como objetivo a satisfação de todas as necessidades legais. Ela contratualiza essas determinações nos artigos 155 (reforma fundiária), 156 (possibilidade de socialização), 159 (direito de associação), 165 (reconhecimento dos princípios da democracia econômica), 161 (reconhecimento do direito à seguridade social). Essas determinações de direitos fundamentais citadas aqui contêm as bases para a estrutura de um Estado Social de Direito, cujo objetivo é 
a realização da liberdade social. Liberdade social significa que o operariado quer determinar por si mesmo seu destino de trabalho, que a determinação heterônoma do trabalho por meio do poder de comando do proprietário sobre os meios de produção precisa dar lugar à autodeterminação.

Havia, além disso, uma "constituição trabalhista" estruturada para além da ideia de igualdade formal, trazendo proteções aos trabalhadores e a possibilidade de ascensão dos mesmos, sendo a igualdade aí concebida positivamente pelo legislador, ou seja, enquanto igualdade substancial. Além da proteção ao trabalhador, o direito passou a influenciar a própria função administrativa exercida pelos detentores dos meios de produção, "mesmo quando o proprietário ainda tem juridicamente a posse dos meios de produção. Nesse caso, o Estado e a sociedade organizada comandam a administração sobre os meios de produção". O jurista relata, ainda, que consoante o "artigo 151, parágrafo 1, a administração desses meios de produção tem por objetivo a garantia de uma existência digna para todos. Do ponto de vista organizacional, isso tem que acontecer com a participação igualitária da associação dos empregados" (NEUMANN, 2017, p. 152).

Neumann afirma expressamente que "a tarefa central da teoria socialista do Estado é desenvolver o conteúdo social positivo da segunda parte da Constituição de Weimar e apresentá-lo concretamente", bem como a tarefa da "jurisprudência socialista" seria realizar uma "interpretação socialista" dos direitos fundamentais contidos na Constituição em contraposição à interpretação em voga que reafirma o Estado liberal burguês. Em suma, "a tarefa da política socialista é realizar esses princípios. Quando Kirchheimer pergunta em seu título 'Weimar... e depois?' , que se aproxima fortemente das ordens de ideias comunistas, então a resposta só pode 
ser: em primeiro lugar Weimar!" (NEUMANN, 2017, p. 153, grifos no original).

Em sua segunda tese de doutorado, Neumann já havia se posicionado a respeito da importância do fenômeno jurídico na ordenação da realidade social, figurando o direito como a "ordem específica da subestrutura social". O jurista aponta a conexão incontestável entre o fenômeno jurídico e o fenômeno social, sendo o direito um "aspecto da ordem das vidas humanas". Mas, esta inter-relação entre direito e realidade social não significa coincidência entre ambas as esferas, podendo a realidade mudar enquanto o ordenamento mantém-se inalterado, fenômeno este definido na doutrina alemã como "uma mudança de função, uma mudança de objetivo, ou como uma substituição da base da norma jurídica". O jurista recupera o argumento desenvolvido por Max Weber e Kantorowicz, que afirmaram ser possível chegar ao socialismo sem alterar nenhum elemento do Código Civil o que, para Neumann, seria possível, porém bastante improvável, já que a sociedade socialista não visaria apenas mudar o detentor da propriedade, mas realizar outro regime de propriedade e a democratização do sistema econômico como um todo. Ou seja, uma mudança de tal magnitude, e o conflito de interesses que ela causaria, demandaria a regulação compulsória e a intervenção do Direito e do Estado. Mas, também pode ocorrer a situação inversa, qual seja, pode a norma jurídica ser alterada enquanto a substrutura social permanece a mesma. Para Neumann, "não tem importância social saber se os processos sociais como venda, arrendamento, empréstimo, contrato entre patrão e empregado, etc., devem ser incluídos na exegética jurídica", mantendo-se a formação das normas jurídicas no próprio âmbito da técnica jurídica (NEUMANN, 2013b, pp. 54-58).

A mudança da norma jurídica pode ensejar, evidente- 
mente, uma alteração na realidade social, aquela mudança sendo precedente a esta. $\mathrm{O}$ autor não endossa a equivocada compreensão de que só há mudança social com mudança jurídica, ou seja, seria a mudança jurídica a causa única para a transformação da sociedade. Seria, para ele, uma "vulgaridade" afirmar que a mudança do ordenamento jurídico pode redundar numa mudança social, mas que a transformação jurídica é sempre demandada pelas forças sociais. Uma mudança do Código Civil alemão no sentido da abolição da propriedade privada atingiria o âmago do sistema capitalista, mas uma mudança com tal magnitude só ocorreria com a convergência de forças sociais neste sentido, sendo, portanto, "produto de um processo social". O jurista reforça, com este argumento, a "interdependência entre direito e realidade social” (NEUMANN, 2013b, pp. 58-59).

Especificamente com relação à intervenção do Estado na realidade, Neumann destaca o fato de que a mesma pode se dar para contemplar os mais diversos interesses, desde os interesses sociais mais básicos, como saúde e alimentação, ou como na regulação da jornada de trabalho, do seguro-desemprego, até os interesses do capital financeiro, industrial, agrário, a regulação econômica, a proteção dos consumidores, entre outros. Ou seja, o intervencionismo estatal pode jogar água tanto no moinho do capital quanto no do trabalho. Assim, por exemplo (NEUMANN, 2013b, p. 334-335),

a intervenção deve manter o funcionamento de um sistema econômico competitivo, como no caso da lei alemã contra a competição injusta, que proíbe o uso de métodos injustos pelos competidores; ou, na Inglaterra, as proibições individuais de difamação quanto aos bens; ou pela propagação deliberada de prestações de constas imprecisas em detrimento dos negócios; ou a proibição de se induzir a quebra de contratos. Todas essas regras não interferem nos processos de livre competição, não interrompem seu funcio- 
namento harmonioso; ao contrário, elas visam a proteger este funcionamento e garantir o cumprimento às regras do jogo da livre competição. Essas regras têm a tarefa, portanto, de moralizar a competição, de tornar a competição real. Elas procuram assegurar e garantir a igualdade entre os competidores.

Dada a dualidade da intervenção estatal, o autor destaca a necessidade de se adotar ao menos um modesto número de medidas protetivas da classe trabalhadora, medidas necessárias para a "segurança social do funcionamento do sistema econômico", que serve igualmente à produtividade. O reconhecimento dos sindicatos, por exemplo, "pode ser necessário para a manutenção da livre competição, para a restauração da paz industrial e para o estabelecimento de um certo grau de calculabilidade nas relações entre trabalhadores e empresários" (NEUMANN, 2013b, p. 335).

Como dito, Neumann entende que se a intervenção estatal pode servir ao capital, pode, igualmente, ter papel de certo reformismo social, no sentido de alteração da estrutura econômica. Isto se daria com a atuação do Estado no sentido não de servir à livre competição, mas da mudança econômica, através, por exemplo, do reconhecimento dos direitos da classe trabalhadora nas fábricas, por meio dos conselhos de trabalho, no mercado de trabalho, por meio do reconhecimento dos sindicatos, no mercado de produtos, através da "participação no controle dos monopólios e o estabelecimento de organização estatal além da organização política" (NEUMANN, 2013b, p. 336).

Interessante destacar, ainda, que o Neumann ressaltava a proeminência da política, já que aponta sua relevância para a transformação da economia, e critica a sua redução à lei, às relações calculáveis entre o homem e o Estado, que retira o próprio potencial advindo da política:

A dissolução da política em lei parece remover o risco proveniente da política. Todos querem conseguir tudo sem arriscar 
coisa alguma. A confiança ingênua na reforma social, a educação e constitucionalidade pode colocar a própria democracia em perigo, uma vez que significam o caráter apolítico das massas, que negam ou que não se querem dar conta de que a luta pelo poder político - i.é., a luta pelo controle das organizações coercitivas, pela polícia, pela justiça, pelo exército, pela burocracia e pela política estrangeira - é o agente do progresso histórico. Enquanto a democracia mal interpretava a relação da Economia com a Política, seus inimigos da direita e da esquerda reconheciam claramente a precedência da Política sobre a Economia. Tanto o fascismo como o bolchevismo concordam com esse ponto de vista (NEUMANN, 1969, pp. 290-291).

A direita, por sua vez, nunca negligenciou a importância do político, como pode ser visto nas experiências fascistas, caracterizadas pela presença de um Estado Total, mas que não se imiscui nas relações de poder econômico. Aqueles que detinham o poder econômico almejavam a presença de um Estado forte, mas que escapasse, ao mesmo tempo, do controle e dos anseios populares, nascendo o fascismo não propriamente como reação ao perigo comunista, mas com o intuito de acabar com o movimento democrático que queria racionalizar e democratizar a economia (NEUMANN, 1969, p. 291).

Neumann diz que "a primazia da política sobre a economia foi sempre uma realidade; às vezes, apenas contestada; outras, abertamente conhecida", e que a diferença entre experiências democráticas e ditatoriais não se encontra na relação da política com a economia, sendo equivocada a definição da democracia como "Estado constitucionalista", já que o regime se caracteriza como "Estado que envolve a subordinação do poder social ao poder político, e que torna esse último responsável". O autor afirma que uma diferença fundamental entre democracia e ditadura consiste na existência de limitações ao poder político impostas ao regime democrático, enquanto as experiências ditatoriais 
foram, como se sabe, marcadas pela ausência de restrições, negligenciando o império da lei e os direitos fundamentais. Outra diferença reside na "responsabilidade dos detentores do poder político para com o povo, pois a democracia não é um Governo popular direto, e sim um Governo parlamentar responsável", diferentemente do que ocorre nas ditaduras, em que é patente a irresponsabilidade do detentor do poder político diante de seus cidadãos. Por fim, o jurista aponta o emprego racional do poder político em regimes democráticos, racionalidade esta que se direciona ao controle do poder privado e, ao mesmo tempo, à garantia de uma vida decente e digna para a população (NEUMANN, 1969, p. 295).

José Rodrigo Rodriguez destaca no pensamento de Neumann a centralidade da política e do direito para o entendimento do sistema capitalista, tanto no que diz respeito à reprodução do sistema quanto da perspectiva da práxis revolucionária. Esta função ampla atribuída ao direito pode ser explicada pela mudança na conformação institucional da política, com a inserção da classe trabalhadora no parlamento, o que faz com que o direito não mais cumpra apenas "funções ideológicas". Vislumbra-se, neste ponto, a centralidade da política na reprodução do sistema capitalista, atuando no funcionamento do processo econômico. Haveria, ainda segundo o autor, uma aproximação entre este aspecto da obra neumanniana e a perspectiva de "capitalismo de Estado" de Pollock, mas há diferença relevante que é o fato de que ainda não houve uma absorção total pelo poder estatal do mundo privado, remanescendo "conflitos políticos que se expressam no Direito", havendo, em virtude disso, "espaço para uma praxis revolucionária no interior das instituições" (RODRIGUEZ, 2004, pp. 55, 56, 57).

Neumann, ainda na interpretação de Rodriguez, acredita que o Estado de Direito, originariamente liberal, já 
representa a "realização parcial da utopia socialista", direcionando seus esforços teóricos para desatrelar o Estado de Direito do capitalismo e aproximando-o, por conseguinte, da práxis socialista. Neumann defende uma "dimensão utópica para o socialismo [...] ao afirmar que a realização da Rule of Law permanece incompleta sob o capitalismo". O jurista alemão apontava a incompatibilidade essencial entre Estado de Direito e capitalismo, o que só restaria resolvido com o fim da sociedade de classes. Assim, mesmo na sociedade pós-capitalista, o Estado de Direito seria um elemento central para o seu funcionamento, encontrando sua plena realização na sociedade socialista, que abarca, inclusive, o fim da sociedade privada dos meios de produção. O socialismo representaria, destarte, não o fim do Estado de Direito, mas a sua plenificação, remanescendo, também, a forma jurídica numa sociedade socialista, sendo pertinente pensar, neste sentido, na "revolução na imanência da forma direito, pois abre-se a possibilidade de submeter o mercado, portanto a propriedade privada, aos desígnios políticos da coletividade, via Direito" (RODRIGUEZ, 2004, pp. 57, 58, 59, 60).

Em suma,

sua análise da politização do capitalismo por meio do Direito permite-lhe afirmar, com base em Rousseau e Weber relidos via Marx, que o Estado de Direito já significa a realização parcial do socialismo, ou seja, que a Rule of Law burguesa tem um conteúdo ético que transcende a sociedade dividida em classes, conteúdo ético este que será completamente desenvolvido quando da plena realização do Estado de Direito na sociedade futura, com a supressão da propriedade privada dos meios de produção (RODRIGUEZ, 2004, p. 61).

Giacomo Marramao também destaca a linha "politológica” de Neumann (e Kirchheimer), que destoou da linha majoritária da Escola de Frankfurt, e seu elogio na racionalização atingida pelo sistema weimariano: 
Franz Neumann representou, junto com Otto Kirchheimer, a partir de 1936, no âmbito do Institut für Sozialforschung, emigrado nos Estados Unidos, a orientação politológica destinada a se contrapor vivamente à linha majoritária da Teoria Crítica, com seu anticapitalismo filosófico agregado em torno da categoria de "Estado autoritário". Suas investigações se concentraram, por mais de três décadas (desde a crise de Weimar até a comparação entre os sistemas jurídico-políticos da Europa Continental e o anglo-saxão, pesquisa interrompida por sua morte, ocorrida num desastre de automóvel, em 1954), na afirmação do caráter antecipador, de certo modo paradigmático, do sistema weimariano, o qual, no curso dos anos 20, expandira-se até se tornar "o mais racionalizado do mundo" no que se refere à regulamentação jurídica das relações de trabalho e ao controle democrático-constitucional dos conflitos sociais (MARRAMAO, 1989, p. 171).

Marramao aponta, neste mesmo sentido, a aproximação entre as obras de Laski e Neumann, já que ambas insistem no "apelo" à luta de classes e ao antagonismo:

[...] na comum tendência a assumir o ponto de vista marxista sobre a sociedade antagônica no interior de uma perspectiva que continua a privilegiar fortemente o aspecto político e constitucional de uma crise que aparece a ambos como crise de passagem para uma estrutura pós-liberal do sistema social. Tanto em Laski quanto em Neumann, o apelo à constelação categorial da luta de classes e do antagonismo não coincide nunca com a aceitação de um dogma, mas sim com a exigência de apontar na constitutional crisis um campo de objetos no qual as temáticas da ciência política se cruzem com as categorias críticas do marxismo (MARRAMAO, 1989, p. 186).

Este seria outro ponto de divergência entre as perspectivas de Neumann (e também Kirchheimer) e outros frankfurtianos, como Max Horkheimer, já que aquele realça a instabilidade e o antagonismo em contraste com as visões que propugnam a integração:

Mesmo representando uma antecipação significativa - e, sob os aspectos metodológico e analítico, mais lúcida - das posteriores 
discussões historiográficas entre Totalitarismustheorie e Pluralismustheorie sobre os dilemas interpretativos que se manifestam quando da comparação entre liberalismo, democracia e fascismo como três formas diversas de exercício do poder político na sociedade industrial (autonomia/heteronomia do sistema político, "primado da política" /"primado da economia"), as análises de Neumann e Kirchheimer terminaram, em oposição especular ao ponto de chegada de Horkheimer, por privilegiar nitidamente o momento da instabilidade e do antagonismo em comparação com o da integração (MARRAMAO, 1989, pp. 206-207).

Segundo o teórico italiano, a atualidade do pensamento desenvolvido em Weimar por intelectuais marxistas como Neumman, Kirchheimer e Laski, por exemplo, é evidente em um contexto de crise do Estado Social e das políticas keynesianas. $\mathrm{Na}$ inovadora abordagem destes autores, o Estado passou, à época, por uma transformação não apenas de função, mas ainda em sua própria estrutura, com a mudança em todo o arcabouço constitucional. Seja a partir da década de 1920, seja após a Segunda Guerra Mundial, e aqui de maneira mais intensiva, passou o Estado a dar forma e a direcionar o desenvolvimento econômico, aumentando a sua estrutura e passando a incorporar âmbitos que anteriormente situavam-se na esfera privada. A instituição estatal torna-se, destarte, locus do permanente conflito e, por isso, de busca do estabelecimento de compromissos (MARRAMAO, 1989, pp. 213-214).

\subsection{A luta para além de Weimar}

Marramao afirma que juristas como Kirchheimer e Neumann foram responsáveis por relevante contribuição teórica ao ressaltarem que as mudanças jurídicas e institucionais operadas na República representaram, de certa maneira, fatores de crise, de conflito: 
A contribuição mais relevante (que resultará dos esforços de consideração retrospectiva realizados no curso dos anos 30 por Neumann, Kirchheimer e pelo próprio Fraenkel) consistirá, precisamente, na captação de um aspecto que a intelectualidade social-democrata weimariana tendia a eludir (e que a intelectualidade comunista tendia, ao contrário, a hipostasiar em fórmulas "catastrofistas" pouco úteis para captar a especificidade da conjuntura): ou seja, o fato de que as substanciais transformações da ordem jurídica e institucional da república - e, em particular, a relevância constitucional assumida pelo direito do trabalho, com a passagem do contrato individual ao contrato coletivo - não se limitavam, evolucionisticamente, a realizar ou promover uma simples efetivação democrática da Constituição, mas punham-se sobretudo como fatores de crise, de descontinuidade e, tendencialmente, de bloqueio do sistema político (MARRAMAO, 1989, p. 174).

Marramao, comentando a contribuição teórica de Kirchheimer, aponta a existência de uma mudança institucional importante, que atinge a relação entre Estado e sociedade, incorporando diferentes grupos sociais neste processo:

Contudo, ocorre uma modificação estrutural fundamental, que envolve diretamente as relações entre sistema político e sociedade: as "pulsões que acompanham as transformações das relações entre governo e comunidade financeira e industrial" dependem agora da forma da relação existente entre as diversas forças sociais. O Estado se apresenta assim - segundo uma expressão adotada tanto por Laski como por Neumann em referência ao institucionalismo como um "paralelogramo de forças", "uma comunidade que se apoia organicamente em outras comunidades de ordem inferior" (MARRAMAO, 1989, p. 199).

O filósofo italiano prossegue em sua análise da obra do jurista de Weimar e destaca o deslocamento realizado no "equilíbrio" entre governo e sociedade em favor dos governos, mormente nos de perfil abertamente autocráticos:

Para ilustrar esse aspecto, Kirchheimer assinala um elemento fundamental de descontinuidade com relação à fase anterior à 
crise: enquanto, nessa fase, os "símbolos da política" expressavam diretamente o diagrama "equilibrado" das relações do governo com as associações de interesse financeiras e industriais (pelo que suas transformações eram uma variável dependente das decisões tomadas na esfera económico-produtiva), a partir dos anos 30 "o equilíbrio está definitivamente se deslocando em favor do governo, caracterizando uma tendência mundial que já se completou nos países mais abertamente autoritários" (MARRAMAO, 1989, p. 199-200).

Outra questão de suma importância é que, para o jurista, a aproximação entre sociedade civil e Estado procedida no século XX não redundou, necessariamente, na diminuição das contradições sociais, alterando apenas a forma como os compromissos passaram a ser entabulados, o que teria que envolver os diversos grupos com interesses por vezes antagônicos:

Retomando uma temática teórico-política já enfrentada no início dos anos 30 - no quadro do aceso e dramático debate sobre a Constituição de Weimar - , Kirchheimer afirma que a transição do "poder indireto" para o "poder direto" não tem um mero significado técnico-instrumental, mas indica que desapareceu o tradicional hiato entre Estado e sociedade, que "não há mais contradição entre conteúdo social e forma política de uma sociedade" (no sentido de que, para usar a terminologia habermasiana, as relações sociais de produção foram envolvidas por um processo de repolitização). Também para Kirchheimer, essa transformação longe de assinalar uma supressão ou uma atenuação da estrutura antagonista na sociedade de massa do capitalismo organizado - indica, ao contrário, que ela se deslocou e generalizou para o próprio sistema político: “Na realidade, (...) as contradições não diminuíram de intensidade e somente se modificaram a forma e a estrutura do compromisso. A tendência geral dessa mudança implica uma passagem da forma liberal do compromisso, que era essencialmente uma delimitação dos setores de competência entre indivíduo e governo, para um compromisso entre grupos de poder em conflito" (MARRAMAO, 1989, p. 200-201). 
Bercovici recorda que Kirchheimer via a Constituição de Weimar como uma "constituição sem decisão", na mesma linha interpretativa, ao menos neste ponto, de Carl Schmitt. Na leitura do jurista alemão, o que houve foi uma transladação operada pela burguesia das formas constitucionais do século XIX para o século XX, com o diferencial da inserção de direitos fundamentais sociais. Comprometia-se a construção, em virtude disso, de uma nova ordem socioeconômica, tendo-se em vista a manutenção do aparato burocrático burguês. Neste quadro, Kirchheimer via a democracia reduzida à mera representação do status quo social, o que ficou patente com o abandono do programa constitucional pela burguesia, fato este que não pode ser compensado pela ação proletária, que não se mostrou forte o suficiente para a formação de uma democracia socialista. A Constituição weimariana figurava, portanto, como mero arcabouço formal dos trâmites democráticos, a ser instrumentalizado pelas forças políticas mais poderosas. Restava aos trabalhadores a autêntica política socialista, para além do texto constitucional (BERCOVICI, 2004, p. 35).

Kirchheimer admite que os sistemas eleitorais à época e mesmo os históricos não se apresentam como tendo o propósito de mudar substancialmente as condições sociais e as formas políticas por elas condicionadas, sendo as sociedades humanas transformadas por meio da ação política dos movimentos sociais. Não faria sentido que os detentores do poder estabelecessem um sistema político-eleitoral que viabilizasse a retirada do apoio à ordem social vigente. Os sistemas eleitorais funcionam, ao contrário, com o propósito de manutenção da ordem social existente. Ou seja, segundo o autor, os sistemas eleitorais não são bons ou ruins, corretos ou falsos, em si mesmos, mas enquanto houver divisões sociais no mundo, a conveniência do sistema político-eleitoral 
é determinada pelo propósito político almejado (KIRCHHEIMER, 1969, pp. 44, 45).

O sistema eleitoral que veio com a Constituição de Weimar significou, segundo o autor, que a "idílica" era burguesa havia chegado ao seu fim, pois o proletariado adentrou à arena democrática com direitos iguais. Mas, na verdade, as experiências políticas pós-primeira guerra mostraram que o elevado número de assentos que coube ao proletariado no parlamento alemão não significou um poder político decisivo. A representação proporcional em curso na Alemanha representou uma limitação às classes e ao potencial político que poderia ser por elas explorado. Entretanto, por outro lado, o Estado passa a servir de local da realização dos antagonismos de classe, e os partidos figuram como porta-vozes desta luta no Parlamento (KIRCHHEIMER, 1969, pp. 46, 47).

O Parlamento não mais apresentava a configuração que lhe foi típica no século XIX, perdendo a feição essencialmente burguesa para uma formação dualista no que toca às classes sociais nele inseridas no século XX. Na interpretação liberal o sistema parlamentarista seria, tão somente, um processo técnico de seleção de lideranças políticas. Ocorre que, nas novas configurações políticas do século $X X$, a técnica de escolha de lideranças também se aplicará para além da instituição parlamentar, envolvendo várias organizações classistas, sendo o Parlamento apenas a "arena" mais visível em que se dá a aludida seleção. A Constituição de Weimar conferiu grande influência e poder político ao Parlamento. Mas o povo acaba figurando como elemento inibidor das decisões da instituição, ou mesmo direcionador de suas decisões, como ocorre nos casos de referendo popular, salientando-se, neste caso, que o povo fica à mercê da formulação das questões a serem respondidas por parte das autoridades públicas. Outra questão destacada pelo jurista é que a Constituição 
não conseguiu evitar que as diversas forças econômicas ocupassem posições em consonância com os respectivos poderes econômicos, tendo os blocos de poder econômico tomado posse do Parlamento, usando sua técnica para controlar a luta de classes, e se situando em posição vantajosa no embate político. Ao mesmo tempo, nunca aceitaram bem as mesmas técnicas quando as decisões majoritárias ameaçavam se voltar contra eles próprios (KIRCHHEIMER, 1969, pp. $47,48,50-51)$.

No que diz respeito aos direitos fundamentais, Kirchheimer destaca a mudança operada pelas constituições do século $X X$, não mais compreendendo as proibições e os direitos de caráter negativo, mas trazendo, igualmente, estipulações positivas, exercendo atividades regulatórias em relação à economia. $\mathrm{O}$ sistema de direitos fundamentais da Constituição de Weimar foi incorretamente tachado como um compromisso apresentado como solução para se fazer concessões a ambos os lados da contenda social. Mas Kirchheimer vê em tal visão de "compromisso" a possibilidade de se dar ensejo a interpretações equivocadas. $\mathrm{O}$ modelo weimariano não representou, para ele, um meio solucionador criado que implicou em concessões realizadas a ambos os lados e em regulação sem ambiguidades de determinada questão em determinado período de tempo. Representou, na verdade, uma conexão e o reconhecimento dos mais variados valores, e o fez de forma inaudita na história constitucional, valores estes que refletiam a influência predominante tanto do socialismo quanto do liberal-capitalismo, e mesmo a influência clerical do catolicismo. Nestes termos, um pretenso plano de construção de um programa cultural e social sem ambiguidades, que fosse realizável e pudesse unificar o país em toda a sua diversidade, falhou rotundamente, aponta o autor. Ademais, a própria implementação dos objetivos 
culturais e econômicos dependeria da força dos diversos grupos de interesse em levar adiante os pontos programáticos componentes dos direitos básicos (KIRCHHEIMER, 1969, p. 53-54).

O princípio da igualdade diante da lei, por exemplo, herança da tradição liberal clássica, que num primeiro momento serviu à luta contra as arbitrariedades perpetradas pela monarquia absolutista, passa a funcionar, segundo o autor, como uma mera ficção ou mesmo um instrumento a ser utilizado pelas forças sociais reacionárias. A igualdade formal não se desenvolveu no sentido da igualdade material, substantiva, econômica, servindo aquela cláusula tão somente para a manutenção da ordem socioeconômica existente. Destarte, se da primeira perspectiva liberal o princípio servia à defesa contra o arbítrio da administração estatal, hoje serve à garantia da ordem social, e num sistema socialista servirá ao estabelecimento das bases da igualdade econômica (KIRCHHEIMER, 1969, p. 55).

Kirchheimer entendia que os direitos fundamentais, em geral, não conseguiram cumprir com suas funções básicas. Estes direitos se caracterizam pela ambiguidade, o que tem intensificado, consideravelmente, a ausência de capacidade de decisão política característica da vida política ao tempo do autor. Estes direitos não viabilizaram um Estado democrático com um suporte programático claro para si e para seus órgãos (KIRCHHEIMER, 1969, p. 60).

$\mathrm{Na}$ leitura de Bercovici, Kirchheimer situa a luta pelo poder econômico no âmbito da distribuição. Na República de Weimar, os trabalhadores tinham representação parlamentar, o que evidentemente é elemento incômodo ao poder econômico e que o leva a tentar atenuar o poder político do Legislativo, tentando blindar a esfera da distribuição das ingerências políticas. Buscou-se, à época, a neutralização 
de determinados setores econômicos tendo em vista barrar a influência dos órgãos de representação popular (BERCOVICI, 2004, p. 104).

O jurista alemão destaca que o problemático esforço em regular a vida econômica será de fundamental importância para o edifício constitucional weimariano como um todo. É um sistema constitucional que protege a propriedade privada ao mesmo tempo em que prevê, expressamente, a possibilidade de sua transformação em propriedade comunal. A menção aos dois modelos díspares de propriedade leva ao entendimento de que seria possível transformar um sistema em outro, já que o artigo 153 da Constituição não garante inequívoca e absolutamente a propriedade privada. Mas o jurista lembra que mesmo as constituições burguesas preveem excepcionalmente a possibilidade de expropriação da propriedade privada em casos de interesse público ou satisfação de uma necessidade concreta específica. Assim, não houve inovação digna de nota, nem mesmo alteração do status quo econômico na Alemanha em virtude do citado dispositivo constitucional (KIRCHHEIMER, 1969, pp. 56-59).

Kirchheimer aponta o princípio da legalidade como a forma através da qual grande parte das decisões atinentes à "esfera da distribuição" são realizadas de forma aparentemente jurídica. A legalidade incorporará, também, as lutas sociais, transformando-as em processos legais, normatizados, o que deu aos trabalhadores possibilidade de operar juridicamente em áreas que antes não possuíam influência alguma. Isso não significou paridade de armas nos embates sociais. As relações de poder continuaram a determinar a direção da atividade administrativa, bem como influenciaram bastante a própria atividade judicial, que em muito lembrou a do início do século, primando pela manutenção da ordem, proteção da propriedade privada e garantia do sistema econômico capitalista (KIRCHHEIMER, 1969, p. 65-67). 
A Alemanha de então suscitou a esperança de transformação ${ }^{4}$ do modelo socioeconômico burguês através da abertura proporcionada pelos novos direitos fundamentais incorporados pelo constitucionalismo weimariano, e por meio do aparato burguês já estabelecido, voltados para a construção de uma nova ordem social, tudo sob a aparência da legalidade (KIRCHHEIMER, 1969, p. 72, 73). Infelizmente, o desenrolar dos fatos históricos não pôde respaldar tal esperança, sendo o desfecho da triste história da República de Weimar por todos conhecido.

Ester Gammardella Rizzi, em ampla análise sobre o pensamento de Kirchheimer, destaca ponto interessante da posição do autor sobre o fato das constituições representarem o ponto de chegada das revoluções, sucedendo-as. Assim, as constituições não teriam função preparatória para eventos revolucionários, mas, ao contrário, visariam formalizar objetivos da nova conformação jurídico-política, com a durabilidade e estabilidade próprias de um texto normativo, representando os anseios de determinado momento histórico. No entanto, é evidente que esta estabilidade não é absoluta, tendendo o poder instituído juridicamente a sucumbir em momentos de crise, diante do poder social, especialmente o poder econômico. Não há paridade entre a ordem constitucionalmente instituída e a ordem do poder social e econômico, figurando a ordem jurídica como elemento mediador privilegiado entre a força social (que deve passar pelos procedimentos jurídico-democráticos) e a realidade (RIZZI, 2011, pp. 98, 99, 100). Bercovici, no mesmo sentido,

4 Esta esperança foi acalentada pelo próprio movimento operário, ou parte dele: "For whereas the entrepreneurs regarded this arrangement as making the maximum of their concessions, the whittling down of which they then made the goal of their subsequente policy, the trade unions saw the new achievement as providing a peaceful and riskless point of departure for the further pursuit of thier socialist goals" (KIRCHHEIMER, 1969, p. 37). 
diz que, para o autor, "o concreto desenvolvimento da Constituição de Weimar na direção do socialismo só poderia ser fruto da luta política dos trabalhadores". E, neste sentido, "as revoluções não são um produto das constituições, mas as constituições são, quase sempre, o monumento de uma revolução vitoriosa" (KIRCHHEIMER, apud BERCOVICI, 2004, p. 147).

A constituição traria, também, um viés para além da limitação do poder e da garantia das liberdades, que consiste em consagrar elementos de uma vida socialmente almejada, trazendo expressos os objetivos a serem buscados em determinado período histórico. Mas resta evidente que nem toda possibilidade está aberta à realização, já que não se pode olvidar da realidade efetiva dos poderes sociais e da realidade histórica. Neste sentido, deve a constituição "responder aos imperativos de adaptação à realidade que quer regular, por um lado e, por outro, ter pretensões transformadoras dessa mesma realidade" (RIZZI, 2011, p. 100).

Kirchheimer entende que a Constituição de Weimar é a tentativa de conciliação de dois constitucionalismos considerados antagônicos, mantendo o texto normativo a indecisão entre os dois. Havia um patente fosso entre os objetivos constitucionalmente estipulados e o aparato estatal ainda arrimado em princípios liberais e, portanto, inadequado para a implementação dos anseios sociais consagrados. Se num primeiro momento o jurista se mostrou crítico a tal arranjo constitucional e ao "hamletismo" da Constituição de Weimar, como autêntico discípulo de Carl Schmitt, depois passou a defender enfaticamente o texto constitucional contra as investidas autoritárias dos que queriam deformar seu sentido. A decisão do projeto constitucional alemão de então passou a ser situada no projeto conciliador e democrático de sociedade que tinha base no texto constitucional (RIZZI, 2011, p. 100). 
Por fim, reproduz-se a ótima síntese da concepção de Kirchheimer sobre o papel (limitado) da constituição na transformação da sociedade, elaborada por Ester G. Rizzi:

Em síntese, uma Constituição, para Kirchheimer, é um instrumento jurídico que mereceria máximo cuidado político e reflexão em seu momento de elaboração, exatamente porque é nela que se expressam os "verdadeiros" anseios para a vida em sociedade de uma determinada comunidade política. A reflexão - e a disputa política - que as escolhas constitucionais merecem se justificam porque a constituição é, sim, instrumento capaz de promover transformações em uma dada realidade política. O potencial de intervenção de uma constituição na realidade, porém, não é infinito nem desprezível. Ela representa, assim, características idênticas aos desejos de transformação coletivamente organizados, os quais costuma acompanhar (RIZZI, 2011, p. 101).

\section{Estado Social entre o ideal e a realidade: os limites de um paradigma}

Se Estado e constitucionalismo social representaram a tentativa de reaproximação entre democracia e constitucionalismo, ainda não se pode dizer que houve uma conformação ideal de um modelo institucional em convivência (e fazendo parte) de um regime efetivamente voltado para a soberania popular.

A primeira parte deste texto trouxe o esforço teórico em torno de Weimar, com posicionamentos diversos acerca das possibilidades contidas naquela experiência histórica. A vinculação com o constitucionalismo social trouxe a esperança de uma autêntica mudança da realidade através da instrumentalização do direito. Cabe, no entanto, relativizar tal potencialidade mudancista, indicando o papel (limitado) das Constituições progressistas que foram promulgadas no 
correr do século XX, sendo a alemã de 1919 paradigmática para a época, e dos direitos sociais que compõem seu núcleo e concentram a substância privilegiada para a tentativa de se erigir um patamar mínimo de vida digna e a alteração das condições socioeconômicas para os desfavorecidos.

Há quem conceba os direitos sociais como elementos de concretização da igualdade:

Assim, podemos dizer que os direitos sociais, como dimensão dos direitos fundamentais do homem, são prestações positivas proporcionadas pelo Estado direta ou indiretamente, enunciadas em normas constitucionais, que possibilitam melhores condições de vida aos mais fracos, direitos que tendem a realizar a igualização de situações sociais desiguais. São, portanto, direitos que se ligam ao direito de igualdade. Valem como pressupostos do gozo dos direitos individuais na medida em que criam condições materiais mais propícias ao auferimento da igualdade real, o que, por sua vez, proporciona condição mais compatível com o exercício efetivo da liberdade (SILVA, 2004, p. 285-286).

No mesmo sentido, Bonavides (2009, p. 564) se refere aos direitos de segunda geração "introduzidos no constitucionalismo das distintas formas de Estado social, depois que germinaram por obra de ideologia e da reflexão antiliberal do século XX", como inseparáveis do princípio da igualdade, já que apartá-los "equivaleria a desmembrá-los da razão de ser que os ampara e estimula".

A princípio, os direitos sociais foram vistos como elementos de efetiva mudança do Estado, ao mesmo tempo em que os trabalhadores esperavam pelo protagonismo no desenvolvimento das políticas sociais:

Consciente das transformações históricas do Estado, o movimento dos trabalhadores declarava ser o sujeito das políticas do Welfare e não meramente o seu objeto. Não se tratava simplesmente de reconhecer as condições de hipossuficiência, de positivar direitos sociais ou implementar políticas de seguridade social. Os direitos 
sociais eram concebidos como uma forma de transformação do Estado e de superação da dicotomia Estado e Sociedade Civil, com a conquista histórica pela classe trabalhadora da verdadeira emancipação social (BERCOVICI; MASSONETTO, 2004, p. 511).

Gosta Esping-Andersen também vislumbrou nos direitos sociais um instrumento que propiciaria a já mencionada "desmercadorização" do trabalhador, relativizando o seu tratamento como uma mercadoria, pois conferia ao mesmo a possibilidade de subsistir sem depender do mercado. Adverte o autor que a desmercadorização só ocorre se efetivamente libertar o trabalhador desta dependência, não sendo suficiente uma política qualquer de assistência social que não tenha o mencionado conteúdo emancipatório. Ademais, a dependência em relação ao mercado funciona como entrave à ação de classe por parte dos trabalhadores. Já a emancipação por meio dos direitos sociais fortalece o trabalhador e enfraquece o patronato, amenizando a diferença entre os que estão incluídos no mercado de trabalho e os que não estão, o que sem os direitos, as políticas e os serviços sociais, significaria cisão e enfraquecimento da classe (ESPING-ANDERSEN, 1991, p. 102).

Mas a realidade dos direitos sociais não é apenas essa. Se eles possuem um inegável elemento de proteção ao trabalhador, de melhoria relativa de sua condição de vida, há outros aspectos que também devem ser considerados se o objetivo for analisar criticamente o papel efetivamente exercido pelos direitos de segunda dimensão na mudança da realidade e seu impacto na questão social.

Um primeiro problema a ser apontado é a sua evidente falta de efetividade em determinados países, apontada, entre outros, por Paulo Bonavides (2009, p. 564-565), “em virtude de sua própria natureza de direitos que exigem do Estado determinadas prestações materiais nem sempre resgatáveis 
por exiguidade, carência ou limitação essencial de meios e recursos". O eminente constitucionalista ainda destaca o fato de que tais direitos foram relegados ao âmbito programático, dada a ausência de garantias ligadas a instrumentos processuais adequados à proteção dos direitos sociais, como muitas vezes observadas no que diz respeito aos direitos de primeira dimensão. Bonavides entente, entretanto, que o fim desta ineficácia estaria próximo na medida em que algumas das novas constituições (como a brasileira de 1988) trouxeram em seu bojo um dispositivo determinando a aplicabilidade imediata dos direitos fundamentais, conferindo a mesma justiciabilidade aos direitos de segunda dimensão que já é conferida aos direitos fundamentais liberais. As quase três décadas da Constituição social e democrática de 1988 denotam que as otimistas observações do festejado constitucionalista não se concretizaram, infelizmente.

Bercovici (2009, online), numa senda que coloca o problema dos direitos constitucionais como problemas (também) políticos, destaca o caráter mudancista do texto constitucional brasileiro, que consagrou um "programa nacional-desenvolvimentista", ao mesmo tempo em que aponta o "estranhamento" entre a Constituição e o Estado brasileiro:

Ela [Constituição brasileira de 1988] continua a ser uma constituição democrática e social (ou programática), mas vai um pouco além: é também uma constituição dirigente. A Constituição de 1988 possui expressamente um plano de transformação da sociedade brasileira, com o reforço dos direitos sociais, a proteção ao mercado interno (artigo 219), o desenvolvimento e a erradicação da miséria e das desigualdades sociais e regionais (artigos $3^{\circ}$ e 170) como objetivos da República, isto é, com a inclusão do programa nacional-desenvolvimentista no seu texto. No entanto, constituição e Estado continuam se estranhando mutuamente.

As sucessivas reformas sofridas pelo texto constitucional, mormente a "reforma regulatória" da década de 1990, 
deram ensejo a uma nova modalidade de patrimonialismo, segundo Bercovici, com a captura do fundo público acompanhada do desmonte da instituição estatal e o esvaziamento do direito econômico enquanto instrumento fundamental para a ação do Estado, reduzido agora à regulação jurídica em moldes privatísticos. Este fato contribuiu para que a Constituição, embora imbuída do "papel de consagrar as bases de um projeto nacional, de um plano de transformações, de implementadora de políticas públicas e de estruturadora do Estado", teve estas finalidades reduzidas a uma mera pretensão inalcançável, e tudo isso com o "silêncio ensurdecedor", ou mesmo a contribuição efetiva, da doutrina publicista brasileira (BERCOVICI, 2009, online):

A própria doutrina constitucionalista brasileira, o que é outra tradição nossa, contribui para isso, com a auto-intitulada "Doutrina Brasileira da Efetividade" e a redução do debate constitucional às questões envolvendo a dicotomia entre regras e princípios ou às questões hermenêuticas e de interpretação, consagrando um deslocamento, que não necessariamente corresponde à realidade política, do centro do sistema constitucional da esfera dos poderes executivo e legislativo para o âmbito do poder judiciário (...).

Ocorre, no Brasil pós-1988, algo paradoxal: os cientistas políticos e sociólogos buscam, cada vez mais, compreender o funcionamento das instituições e seu regime jurídico-constitucional. Já os constitucionalistas, por sua vez, refugiam-se nos debates sobre a aplicação judicial das normas e da hermenêutica e interpretação constitucionais, tornando o judiciário praticamente o único setor estatal estudado e analisado por um direito público que se pretende democrático, mas não fala de democracia (BERCOVICI, 2009, online).

\section{Em síntese, Bercovici afirma que}

neste contexto, persistem, inclusive, ameaças ao regime democrático, com a deslegitimação da representação popular, dos instrumentos de democracia participativa e do próprio Estado, 
privado de meios para atuar, com a retirada de extensos setores da economia do debate público e democrático no Parlamento e do poder decisório dos representantes eleitos do povo. No Brasil pós-1988 há, portanto, um "descolamento" entre o Estado, desestruturado, privatizado, patrimonialista e ainda autoritário, e a constituição, meramente normativa, sem meios efetivos de ser concretizada. Mas, falar de Estado, de política e de poder, para a doutrina constitucionalista dominante no país, não é um assunto do direito constitucional. Como afirmei no início, trata-se de um diálogo entre ausentes em meio a um silêncio ensurdecedor de nossos publicistas... (BERCOVICI, 2009, online).

Boa parte da doutrina do Direito Constitucional, quando imbuída de espírito crítico, faz a denúncia da falta de efetividade dos direitos sociais e a partir disso busca pensar (dogmaticamente) uma saída para o problema. As discussões se concentram na teoria da efetividade das normas constitucionais ou, quando vai um pouco além, na hermenêutica constitucionalmente adequada dos direitos fundamentais de segunda dimensão. Sem menosprezar o trabalho teórico dos que envidam esforços para a construção de uma dogmática (ou hermenêutica) crítica, tal direcionamento hegemônico na busca da solução da inefetividade dos direitos sociais recai sobre o idealismo de se buscar soluções teóricas (muitas vezes estéreis) no fechado âmbito do direito constitucional. Como se os problemas atinentes ao texto constitucional fossem apenas problemas estritamente jurídicos, menosprezando-se seu teor também eminentemente político. Assim, urge destacar que a inefetividade da constituição é um problema político-jurídico e, desta forma, não há como debelá-lo apenas fazendo uso da dogmática constitucional, por mais sofisticado que tal uso se mostre.

Carlos Miguel Herrera (2007, p. 373, 374), que vai muito além da crítica supramencionada, destaca a existência de "uma tensão própria aos direitos sociais entre dois polos, de emancipação social, por um lado, e de integração social, 
pelo outro, e que condiciona, por sua vez, o par conceitual utilizado para determinar seu caráter, universalidade e particularidade". O jurista destaca que os direitos sociais, diferentemente dos individuais, resultariam de uma "revolução inconclusa", pois os movimentos a ela ligados não conseguem executar o seu programa e, além disso, se estabelece a ideia que o evento revolucionário deve ser finalizado por uma nova constituição, um novo ordenamento jurídico que o consagre. Nesse último ponto, vê-se que não há diferença com relação ao constitucionalismo liberal, já que o seu congênere social também se prestou a terminar a revolução, apaziguando os ânimos mudancistas advindos das lutas que o antecederam. Ele observa que, "desde o início, a ideia de direitos sociais, e mais particularmente, esta referência direta ao social, expressa esse ponto de passagem consciente da insurreição à instituição através de sua positivação (constitucionalização)".

Resta evidente, portanto, que o constitucionalismo, em seus diferentes matizes, sempre opera no sentido de amainar a efervescência das lutas mudancistas para, em seu lugar, entronizar uma nova "ordem" derivada, cumpre reconhecer, de alguns dos ideais que serviram de combustível revolucionário. Ou seja, verifica-se sempre a presença do binômio mudança-conservação, de modo que parece ser impossível (ao menos é o que a experiência histórica mostra, notavelmente a de Weimar) chegar a um modelo diverso do capitalismo valendo-se, para tanto, dos instrumentos jurídicos do constitucionalismo.

Herrera (2007, p. 380) evoca o exemplo histórico da Constituição Mexicana de 1917, que inaugura o constitucionalismo social, e representa a primeira vez em que os direitos sociais dispostos em um texto constitucional estavam patentemente relacionados à ideia de revolução inconclusa: 
Esta tensão entre integração e emancipação inscreve-se no próprio coração do dispositivo constitucional. Embora se reconheça, pela primeira vez com estatura constitucional, o direito de greve, o contrato de trabalho, a participação dos trabalhadores nos lucros das empresas, interpretados como princípios dinâmicos para a transformação social, estes estão ao mesmo tempo enquadrados - assim, a greve é lícita se ela "harmoniza os direitos do trabalho com o capital" (HERRERA, 2007, p. 382).

Foram abordadas, acima, algumas posições que viam no Estado Social um caminho democrático e alicerçado nas regras constitucionais para se chegar ao socialismo. Herrera (2007, p. 391), sobre isso, traz o posicionamento de Eduard Heimann que entendia que as políticas sociais dariam materialidade a ideias sociais no capitalismo, mas que se colocariam contra o próprio sistema socioeconômico. $\mathrm{Ou}$ seja, os direitos sociais implicariam o enfraquecimento do poderio do capital sobre o trabalho e, portanto, mudariam o equilíbrio entre as classes, dada a redução da dependência do proletariado com relação ao mercado. Assim, a política social figuraria como um "cavalo de troia" instalado no capitalismo que permitiria sua própria superação em direção ao socialismo. A história, até o presente momento, vale reiterar, desautoriza tamanha expectativa de socialização através da democracia liberal-parlamentar (ESPING-ANDERSEN, 1991, p. 89).

Herrera aponta, ainda, que a ligação entre direitos sociais e transformação social se debilitará após a Segunda Guerra, após a relativa generalização dos Estados de Bem-Estar Social e a relativa aceitação geral dos direitos sociais nas Constituições. Ojurista aponta a irrefutabilidade da ligação entre o Estado Social e certa mudança na realidade, com a tentativa de diminuição das desigualdades sociais. Mas é igualmente verdadeiro que "o Estado intervencionista tal como se desenvolve a partir de 1945, produz sempre trans- 
formações tendo em vista a integração social ${ }^{5}$, separando, de fato, a política (social) dos direitos (sociais)" (HERRERA, 2007, pp. 374, 391):

Os desenvolvimentos constitucionais na segunda metade do século XX debilitarão a relação entre constitucionalização de direitos sociais e mudança social. Com efeito, esta segunda onda de constitucionalismo social, que surge em países liberados de ditaduras totalitárias, vai constitucionalizar os direitos sociais em uma direção particular, a da integração social. É também o momento em que se opera uma coincidência entre o reconhecimento dos direitos sociais e o desenvolvimento de um Estado intervencionista de novo tipo, o Estado de Bem-Estar. Nesta constelação concreta e complexa fixam-se os fundamentos jurídicos dados aos direitos sociais até nossos dias (HERRERA, 2007, pp. 385-386).

A doutrina alemã construiu, neste contexto, a ideia de "direitos-diretivas", dirigidos ao legislador, pois " a partir do momento em que a realização de um direito social implica em gasto econômico, a decisão não pode ultrapassar a esfera do legislador ou da administração, sob o risco de politizar a justiça". Destaca-se o elemento discricionário na realização

5 Ademais, há sempre a tentativa de "normalização" dos textos constitucionais progressistas (fenômeno também observado no Brasil, na década de 1990): "As novas constituições européias dos anos 70 compartilharão com suas antecessoras desta segunda metade do século XX o fato de surgirem após (longas) experiências ditatoriais. Mas, sobretudo, prolongavam de alguma maneira as experiências italiana e alemã no plano do constitucionalismo social. A codificação mais ambiciosa de direitos sociais encontra-se na Constituição de Portugal, de 1976, surgida da chamada "Revolução dos Cravos", e talvez fosse tentador inscrever os diferentes níveis de juridicidade alcançados pelos direitos sociais entre esta constituição e sua contemporânea espanhola, de 1978 - que, como vimos no início, prefere falar já só de "princípios dirigentes" (principios rectores) -, na distância que separa uma passagem à democracia constitucional por via insurrecional, em um caso, ou transicional, em outro. Mas as revisões constitucionais portuguesas, de 1982 e 1989, "normalizaram" rapidamente algumas de suas potencialidades normativas, inscrevendo-as no marco do Estado de Bem-Estar" (HERRERA, 2007, p. 388). 
dos direitos sociais, elemento este típico do vetusto modelo estatal bismarckiano que afastava a possibilidade de uma política social mais ativa do reconhecimento efetivo dos direitos fundamentais às mesmas (HERRERA, 2007, p. 389-390).

Lembra Bercovici, a este respeito, que a ideia de uma Constituição Dirigente, peculiar ao Estado Social, se conecta à defesa da transformação da realidade por meio do direito: “O sentido, o objetivo da Constituição Dirigente é o de dar força e substrato jurídico para a mudança social. A Constituição Dirigente é um programa de ação para a alteração da sociedade". Ocorre que essa teoria acaba por recair no erro de ser uma "Teoria da Constituição centrada em si mesma", "autossuficiente", com tamanha envergadura que a Constituição, por si só, serviria de panaceia para todos os males sociais, sendo o texto constitucional suficiente para alterar a sociedade, minimizando o Estado e a política e suas respectivas teorias. Ocorre que a Constituição é um documento político e jurídico, não podendo ser reduzida a uma análise meramente normativa. A reflexão política (e estatal) é essencial para a compreensão realista dos problemas que envolvem a Constituição enquanto documento "resultante e determinante da política" (BERCOVICI, 2004, pp. 12-13, 24).

Flávio Roberto Batista acrescenta que a ideia de constituição dirigente foi aqui assimilada com foco na questão das normas programáticas, que podem ser cumpridas na medida em que o Estado tenha recursos para tanto. Ou seja, de constituição que aponta na direção da transição para o socialismo, consoe defendido por alguns autores (inclusive Canotilho), passou-se à direção jurídica da ação do Estado para realização da justiça social, distanciando-se, portanto, da ideia de mudança no modo de produção (BATISTA, 2012, p. 148-149).

Já para Tarso de Melo, a Constituição brasileira de 1988 abarca a dinâmica entre conservação e mudança social figurando como um projeto quase revolucionário de transfor- 
mação. Lembra Tarso que os ataques ao texto constitucional promovidos pelos defensores do neoliberalismo são sintomas de que ali reside um espaço privilegiado de luta que deve ser levado em conta pelos dominados. As lutas seculares dos trabalhadores por direitos fazem parte da história, não podem ser negligenciadas, e mesmo as lutas pontuais podem servir como elementos desencadeadores de lutas maiores, mais aglutinadas, e mesmo do desenvolvimento da consciência de classe dos desfavorecidos. E os objetivos a serem atingidos pelas lutas, mesmos as mais delimitadas, não podem ser previamente definidos, de antemão demarcados. Portanto, segundo autor, as lutas que se inserem no âmbito do capital podem se desdobrar para além da reinvindicação dentro do próprio sistema socioeconômico, apontando para horizontes de sua superação. Negar tal possibilidade seria agir como senhor do destino, possibilidade ainda não franqueada ao gênero humano. Não se deve, nesse sentido, separar "guerra" e "guerrilha" contra o capital, sendo a luta por direitos encarada como instrumento de ação para além das necessidades vitais mais prementes, o que pode redundar na radicalização dos direitos sociais (MELO, 2011, pp. $54,65-66,68,74-75)$.

\section{Apontamentos finais}

Conclui-se o presente texto endossando, em sentido próximo ao desta "ambiguidade" dos direitos (especialmente dos direitos sociais) apontada por Tarso de Melo, o fato apontado por Flávio Roberto Batista de que se a mudança de modelo socioeconômico não virá por meio do direito, cabe identificar as bandeiras que merecem ser portadas no combate à lógica mercantil e sua aplicação no âmbito jurídico (BATISTA, 2012, p. 197).

O embate progressivo pela radicalização dos direitos sociais, o uso da "ambiguidade", ou mesmo da "dupla ins- 
trumentalidade" (Cf. REICH' ${ }^{6}$, 1985) do direito não devem ser menosprezadas, o que não significa desconsiderar os limites a eles inerentes. É que, como disse Claude Lefort (2011), "seguramente, nem tudo é possível a cada momento; mas, os limites do possível, ninguém os conhece".

\section{Referências bibliográficas}

BATISTA, Flávio Roberto. Crítica da tecnologia dos direitos sociais: uma contribuição materialista histórico-dialética. Tese de Doutorado apresentada ao Departamento de Direito do Trabalho e Seguridade Social da Universidade de São Paulo, 2012.

BERCOVICI, Gilberto. Constituição e estado de exceção permanente: atualidade de Weimar. Rio de Janeiro: Azougue, 2004.

. Estado intervencionista e Constituição Social no Brasil: o silêncio ensurdecedor de um diálogo entre ausentes. In: SOUZA NETO, Cláudio Pereira de; SARMENTO, Daniel; BINENBOJM, Gustavo. (Org.). Vinte anos da Constituição Federal de 1988. Rio de Janeiro: Lumen Juris, 2009. Disponível em: <xa.yimg.com/kq/groups/22789978/2041661191/name/ Bercovici...>.

. O poder constituinte do povo no Brasil: um roteiro de pesquisa sobre a crise constituinte. Lua Nova, São Paulo, n. 88, p. 305-325, 2013.

6 Así pues, el derecho resulta de este modo instrumentalizado doblemente: por parte del Estado (social) y por parte de los agentes que actúan en el mercado; y precisamente en ello, como se verá, hay que buscar la razón de la contradicción fundamental que existe en el moderno derecho de la economía. La ideología de um derecho unitario presenta ya fisuras considerables; los conflictos entre economía y politica se reproducen ahora en el plano del derecho (REICH, 1985, p. 61). 
BONAVIDES, Paulo. Curso de Direito Constitucional. São Paulo: Malheiros, 2009.

ESPING-ANDERSEN, Gosta. As três economias políticas do Welfare State. Lua Nova, n. 24, pp. 85-116, 1991.

HELLER, Hermann. Teoria do Estado. São Paulo: Mestre Jou, 1968. 1985.

. Escritos políticos. Madri: Ed. Alianza Universidad, . Démocratie politique et homogénéité sociale. Cités - Presses Universitaire de France, vol. 6, no. 2, pp. 199-211, 2001.

HERRERA, Carlos Miguel. Constitution et social-démocratie à Weimar: pour une périodisation. In: HERRERA, Carlos Miguel (org.). Les juristes de gauche sous la République de Weimar. Paris: Kimé, 2002.

. Estado, constituição e direitos sociais. Revista da Faculdade de Direito da Universidade de São Paulo v. 102 p. 371 - 395 jan./dez. 2007.

A política dos juristas. São Paulo: Alameda, 2012.

HOBSBAWM, Eric. Globalização, democracia e terrorismo. Tradução de José Viegas. São Paulo: Companhia das Letras, 2007.

KIRCHHEIMER, Otto. Weimar - and what then? In: Politics, Law, and Social Change. Selected Essays. Edited by Frederic S. Burin and Kurt L. Shell. Nova Iorque e Londres: Columbia University Press, 1969.

LEFORT, Claude. A invenção democrática: os limites da dominação totalitária. Belo Horizonte: Autêntica, 2011.

MARRAMAO, Giacomo. O político e as transformações: crítica do capitalismo e ideologias da crise entre os anos vinte e trinta. Belo Horizonte: Oficina de Livros, 1990. 
Política e "complexidade": o estado tardio capitalista como categoria e como problema teórico. In: HOBSBAWM, Eric. História do marxismo: o marxismo hoje (segunda parte). São Paulo: Paz e Terra, 1989.

MASSONETTO, Luís Fernando; BERCOVICI, Gilberto. Breve história da incorporação dos direitos sociais nas Constituições democráticas brasileiras. Revista do Departamento de Direito do Trabalho e da Seguridade Social, v. 3, p. 61-84, 2004.

MELO, Tarso de. Direito e ideologia: um estudo a partir da função social da propriedade rural. São Paulo: Expressão Popular, 2009.

Ambiguidade e resistência: direito, política e ideologia na neoliberalização constitucional. Tese (Doutorado) - Faculdade de Direito, Universidade de São Paulo, São Paulo, 2011.

NEUMANN, Franz. Estado democrático e Estado autoritário. Rio de Janeiro: Zahar, 1969.

. O conceito de liberdade política. Cadernos de Filosofia Alemã, 22, pp.107-154, 2013 a.

. O império do direito. São Paulo: Quartier Latin, 2013b.

A mudança de função da lei no direito da sociedade burguesa. Revista Brasileira de Estudos Políticos, Belo Horizonte, n. 109, pp. 13-87, jul./dez. 2014.

. O significado social dos direitos fundamentais na Constituição de Weimar. Cadernos de Filosofia Alemã, v. 22, n. 1, pp.139-155, 2017.

POLLOCK, Frederick. State Capitalism: Its Possibilities and Limitations. Studies in Philosophy and Social Science (Zeitschrift für Sozialforschung), vol. IX, New York, Institute of Social Research, 1941. 
REICH, Norbert. Mercado y derecho (teoría y praxis del derecho económico en la República Federal Alemana). Barcelona: Ariel, 1985.

RIZZI, Ester Gammardella. Democracia e Transformações Sociais no Estado Parlamentar: Kirchheimer e a República de Weimar. Dissertação de Mestrado apresentada ao Departamento de Filosofia e Teoria Geral do Direito da Universidade de São Paulo, 2011.

RODRIGUEZ, José Rodrigo. Franz Neumann, o direito e a teoria crítica. Lua Nova, n. 61, 2004.

RUGITSKY, Fernando. Friedrich Pollock: limites e possibilidades. In: NOBRE, Marcos. Curso livre de teoria crítica. Campinas-SP: Papirus, 2008.

.; RODRIGUEZ, José Rodrigo. Friedrich Pollock e Franz Neumann. In: NOBRE, Marcos. Curso livre de teoria crítica. Campinas-SP: Papirus, 2008.

SILVA, José Afonso da. Curso de direito constitucional positivo. São Paulo: Malheiros, 2004.

Recebido em 06/08/2018.

Aprovado em 21/10/2018.

Thiago Lemos Possas

E-mail: thiagolp84@yahoo.com.br 
